\title{
Tight Junctions as a Key for Pathogens Invasion in Intestinal Epithelial Cells
}

\author{
Tracy Paradis ${ }^{1}$, Hervé Bègue ${ }^{1}$, Louise Basmaciyan ${ }^{1,2}$, Frédéric Dalle ${ }^{1,2, *}$ and Fabienne Bon ${ }^{1}$ \\ 1 UMR PAM l'Université de Bourgogne Franche-Comté (UBFC), AgroSup Dijon, Equipe Vin, Aliment, \\ Microbiologie, Stress, F21000 Dijon, France; Tracy.Paradis@u-bourgogne.fr (T.P.); \\ Herve.Begue@u-bourgogne.fr (H.B.); Louise.Basmaciyan@u-bourgogne.fr (L.B.); \\ Fabienne.Bon@u-bourgogne.fr (F.B.) \\ 2 Laboratoire de Parasitologie-Mycologie, Plateforme de Biologie Hospitalo-Universitaire Gérard Mack, \\ F21000 Dijon, France \\ * Correspondence: frederic.dalle@u-bourgogne.fr; Tel.: +33-3-8029-5014
}

Citation: Paradis, T.; Bègue, H.; Basmaciyan, L.; Dalle, F.; Bon, F. Tight Junctions as a Key for Pathogens Invasion in Intestinal Epithelial Cells. Int. J. Mol. Sci. 2021, 22, 2506. https://doi.org/10.3390/ ijms22052506

Academic Editors: Véronique Carrière and Sophie Thenet

Received: 11 February 2021

Accepted: 23 February 2021

Published: 2 March 2021

Publisher's Note: MDPI stays neutral with regard to jurisdictional claims in published maps and institutional affiliations.

Copyright: (C) 2021 by the authors Licensee MDPI, Basel, Switzerland. This article is an open access article distributed under the terms and conditions of the Creative Commons Attribution (CC BY) license (https:// creativecommons.org/licenses/by/ $4.0 /$ )

\begin{abstract}
Tight junctions play a major role in maintaining the integrity and impermeability of the intestinal barrier. As such, they act as an ideal target for pathogens to promote their translocation through the intestinal mucosa and invade their host. Different strategies are used by pathogens, aimed at directly destabilizing the junctional network or modulating the different signaling pathways involved in the modulation of these junctions. After a brief presentation of the organization and modulation of tight junctions, we provide the state of the art of the molecular mechanisms leading to permeability breakdown of the gut barrier as a consequence of tight junctions' attack by pathogens, including bacteria, viruses, fungi, and parasites.
\end{abstract}

Keywords: enterocytes; gut barrier; tight junction; intestinal epithelial cells; pathogens; microorganisms; signaling pathways; permeability

\section{Introduction}

A large community of microorganisms (viruses, bacteria, and fungi) and parasites inhabits the intestinal lumen forming the intestinal microbiota. This microbiota includes commensal microbial species that may, for some, become pathogenic following a disruption of the host defenses. The intestinal epithelial barrier segregates microorganisms and/or their components in the gut lumen considered as an external environment from the sterile deep tissues. The separation is achieved in part by intercellular junctions, especially tight junctions (TJ), which ensure impermeability of the gut barrier, avoiding the translocation of both commensal and pathogenic agents [1,2]. Commensal microorganisms have a protective role for the digestive mucosa by participating in maintaining the physiological integrity of TJs which sustain their barrier function during entero-pathogen challenge [3-8]. Among them, probiotics have been reported to potentiate the tightening of TJs, which improve impermeability of the gut mucosa aimed at, among others, counteracting the deleterious action of pathogens upon the TJ complex. In contrast, some pathogenic microorganisms have developed strategies to disorganize the TJs aiming to translocate through the digestive mucosa and invade their host. These entero-pathogens include (i) entero-invasive or entero-toxigenic bacteria (respectively, Shigella, Salmonella, enteroinvasive/enteropathogenic Escherichia coli, Yersinia, Campylobacter, or Vibrio cholerae, enterotoxigenic or hemorrhagic Escherichia coli, Clostridium, and Aeromonas), (ii) enteric viruses that are specific to the digestive tract, such as Norovirus, Astrovirus, and Rotavirus but also viruses such as HIV that can target enterocyte TJs, (iii) parasites causing gastroenteritis (i.e., Entamoeba, Blastocystis, or Giardia), or using intestinal cells as a portal of entry for their dissemination (i.e., Toxoplasma gondii), and (iv) fungi, including the yeast Candida albicans belonging to the gut mycobiote, and other fungi such as Aspergillus and Penicillium that are transitory hosts of the food bolus. 
The cohesion and impermeability of the intestinal epithelium is based on the presence of junctional intercellular complexes formed at the apical level by TJs, adherens junctions (AJs), and desmosomes, all of them interacting with the cytoskeleton (Figure 1) $[9,10]$. Among them, TJs are involved in cell-cell interactions between enterocytes as well as with other intestinal cells, including intraepithelial lymphocytes, $\mathrm{M}$ cells, goblet cells, or dendritic cells. Each of them is associated with specific features and role in the barrier and chemical functions of the intestinal mucosa [11]. TJs form a continuous and tight branched network between membranes of neighboring cells, leading to the complete sealing of the apical intercellular space (Figure 1). In addition, TJ proteins, especially claudins, constitute a barrier inside the membrane itself, preventing the migration of transmembrane proteins and lipids from the apical to the baso-lateral side, therefore participating in enterocyte polarization [12]. Thus, TJs also act as a site for integration and transmission of signals necessary for the regulation of their assembly and for cell polarization. Finally, they participate to the modulation of gene expression required for cell proliferation and differentiation, as well as in stress responses [12-16]. Altogether, the TJ complex consists of a rate-limiting factor in the paracellular permeability, in response to environmental changes which undergo regulations of the integrity of the gut barrier through their opening or sealing. In this context, having a clear view of the mechanisms involved in TJ dynamics is crucial to understand their key role in preventing microbial translocation and spread to deep tissues.

After a brief presentation of the organization and modulation of TJs, this review will focus on the abilities of pathogens to target tight junctions with the aim to promote invasion of the gut mucosa and dissemination into the host.

\section{Structure, Formation, and Modulation of Tight Junctions}

The TJ complex is composed by three family of transmembrane proteins (i.e., the claudin family, the Marvel domain-containing proteins (occludin, tricellulin, and MarvelD3), and immunoglobulin superfamily (JAM, CAR)). This transmembrane structure is bounding to the cytoskeleton through a cytoplasmic TJ plaque composed of scaffold proteins among them the zonula occludens $(\mathrm{ZO})$ proteins 1 to 3 , the cingulin and cingulinlike proteins, and the afadine. Many other proteins involved in signal transduction and membrane trafficking are also associated with TJs (Figure 1). 


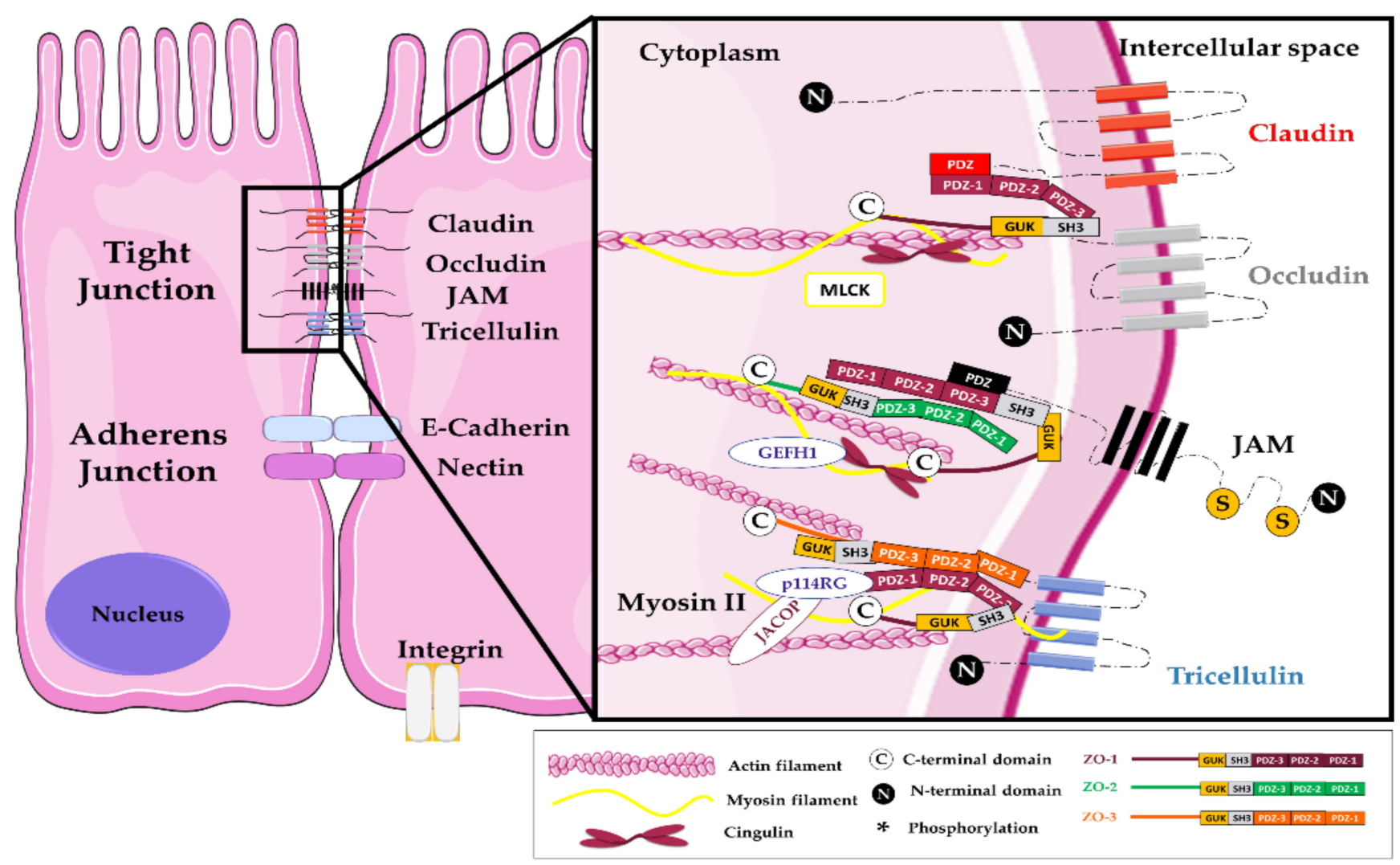

Figure 1. Composition of tight junctions in intestinal epithelial cells. Among the over forty proteins involved in the TJ complex, the transmembrane proteins belong mainly to three groups: the claudins family, the Marvel domain-containing proteins (occludin, tricellulin, also known as MarvelD2 and MarvelD3 proteins), and several immunoglobulin superfamily members ((Junctional Adhesion Molecules (JAMs), Coxsackie and Adenovirus Receptor proteins (CAR)) [17]. Other transmembrane proteins such as BVES (blood vessel epicardial substance), the apical polarity determinant Crb3 (Crumbs Cell Polarity Complex Component 3), and angulins colocalize and interact with TJs at the apical level even if not consensually considered to belong to this junctional complex [18]. These proteins relate to a cytoplasmic plaque formed by adaptor and signaling proteins. Adaptor proteins provide a bridge to the cytoskeleton through actin and microtubule tight bonds and include proteins such as zonula occludens proteins (ZO-1/3), cingulin, paracingulin, also known as junction-associatedcoiled-coil protein (JACOP), membrane-associated guanylate kinases (MAGI 1-3), Multi-PDZ domain protein 1 (MUPP1), Pals, PATJ, Partitioning defective 3 and 6 proteins (Par3 and 6), Merlin-angiomotin complex. Signaling proteins complete this complex network, including protein kinases (atypical protein kinase $\mathrm{C}$ (aPKC), Mitogen-activated protein kinase kinase (MEKK1), complex Cyclin D1/CDK4, Large tumor suppressor kinase 1 (LATS1)), phosphatases (Phosphatase and TENsin homolog (PTEN)), GTPases and their activators (Rap2c, Myosin-IXA, Rho guanine nucleotide exchange factors (PDZGEF1, p114RhoGEF, GEF-H1, ARHGEF11), RICH1, SH3 domain-binding protein 1 (SH3BP1), Tubulin alpha chain (Tuba)), heat shock proteins (Apg-2), and transcriptional and post-transcriptional regulators ((zonula occludens 1-associated nucleic acid binding protein (ZONAB), Symplekin, yes-associated protein 1 (YAP), tafazzin (TAZ)). The last group of proteins localize with the TJ scaffold proteins but move to the nucleus aimed at modulating gene expression. Therefore, they are involved not only in the regulation of the junctional organization and function but also take part in many cells signaling pathways including cellular proliferation, differentiation, and response to many stimuli.

The $\mathrm{Tj}$ formation initiates at apical pole of neighboring immature epithelial cells. The concomitant maturation of both tight and adherens junctions requires the activation of several signaling pathways, namely (i) the complex Par3-Par6-aPKC involving the partitioning defective homolog proteins 3 and 6 (Par-3) (Par-6) and the atypical protein kinase C (aPKC), (ii) several phosphatases (e.g., phosphatase 2A (PP2A)), and (iii) various GTPases (e.g., Raps, Rho GTPases, including RhoA, Rac, and Cdc42) [19-23]. The junctions between epithelial cells are considered functional when TJs and AJs are distinct [12]. 
TJ formation and dissociation are dynamic processes contributing to the modulation of tissue permeability in response to (i) variations in the chemical composition of the intestinal bolus (i.e., type and quantity of proteolytic enzymes, ionic content, and solutes), (ii) the inflammatory state of the intestinal mucosa, and (iii) the gut microbiota composition [24]. These are ensured by the development of vesicular trafficking of TJ proteins between the cytosol and the cell membrane, leading to their destruction and/or their rewiring to the cytosol, that correlates with their degree and sites of phosphorylation. Both changes in their expression and post-transcriptional regulatory mechanisms have also been reported but partially elucidated (Figure 2) [25]. Various exogenous factors and physiological modulators regulate the integrity of the TJs and consequently the intestinal permeability. In this context, the maintenance of the TJ proteins to the junctional complex has been correlated to the activation of kinase pathways including PKC and MAPK (ERK, p38, JNK), the calcium/calmodulin-dependent kinase 2 (CaMKK2)-AMP-activated protein kinase (AMPK), as well as Rho and NF- $\mathrm{kB}$ pathways [25-31]. Currently, zonulin (haptoglobin 2 precursor) remains the only endogenous modulator described as specific for TJs. It was identified as the mammalian analogue of zonula occludens toxin (Zot), secreted by the cholera pathogen Vibrio cholerae [32]. Whereas the secreting cell type remains to be specified, zonulin is produced in the intestinal lumen in response to the luminal presence of gluten and/or during bacterial colonization. In fact, its expression is associated with the presence of both commensal and pathogenic bacteria, with a more intense response to the latter [33,34]. Zonulin is able to activate the EGF receptor through direct binding or through the transactivation of the protease-activated receptor $2\left(\mathrm{PAR}_{2}\right)$. This activation is then followed by the activation of the Ras-MAP-kinase cascade, ending by the removal of ZO-1 proteins from the junctional complex and therefore promoting the relaxation of tight junctions [34,35].

In polarized cells, the peri junctional contractile ring of actin-myosin II intimately interacts with TJ proteins. Consequently, any modification in one of these two connected compartments directly impacts physically the functional organization of the other. For instance, the actin-myosin contraction following the activation of the myosin light-chain kinase (MLCK) mediates intestinal TJ regulation in response to both physiological and pathophysiological stimuli [36]. In the same way, Rho proteins have been suggested to play an important role in maintaining the association of TJs with the membrane [37,38]. Indeed, the kinase ROCK, downstream effector of Rho, is reported to regulate specifically TJs via its effects on the F-actin cytoskeleton [38]. Besides, activation of the EGF receptor, leading to the activation of both $\beta$ and $\varepsilon$ isoforms of the protein kinase $C$ (PKC), as well as the phospholipase $C$, promotes the stabilization of the actin/myosin ring and consequently the TJ complex [39]. To our knowledge, signaling pathways associated to TJ modulation have been reviewed (i) concomitantly in different cellular models other than intestinal epithelial cells (IECs) or (ii) singly or in a specific context in IECs [40-45]. 


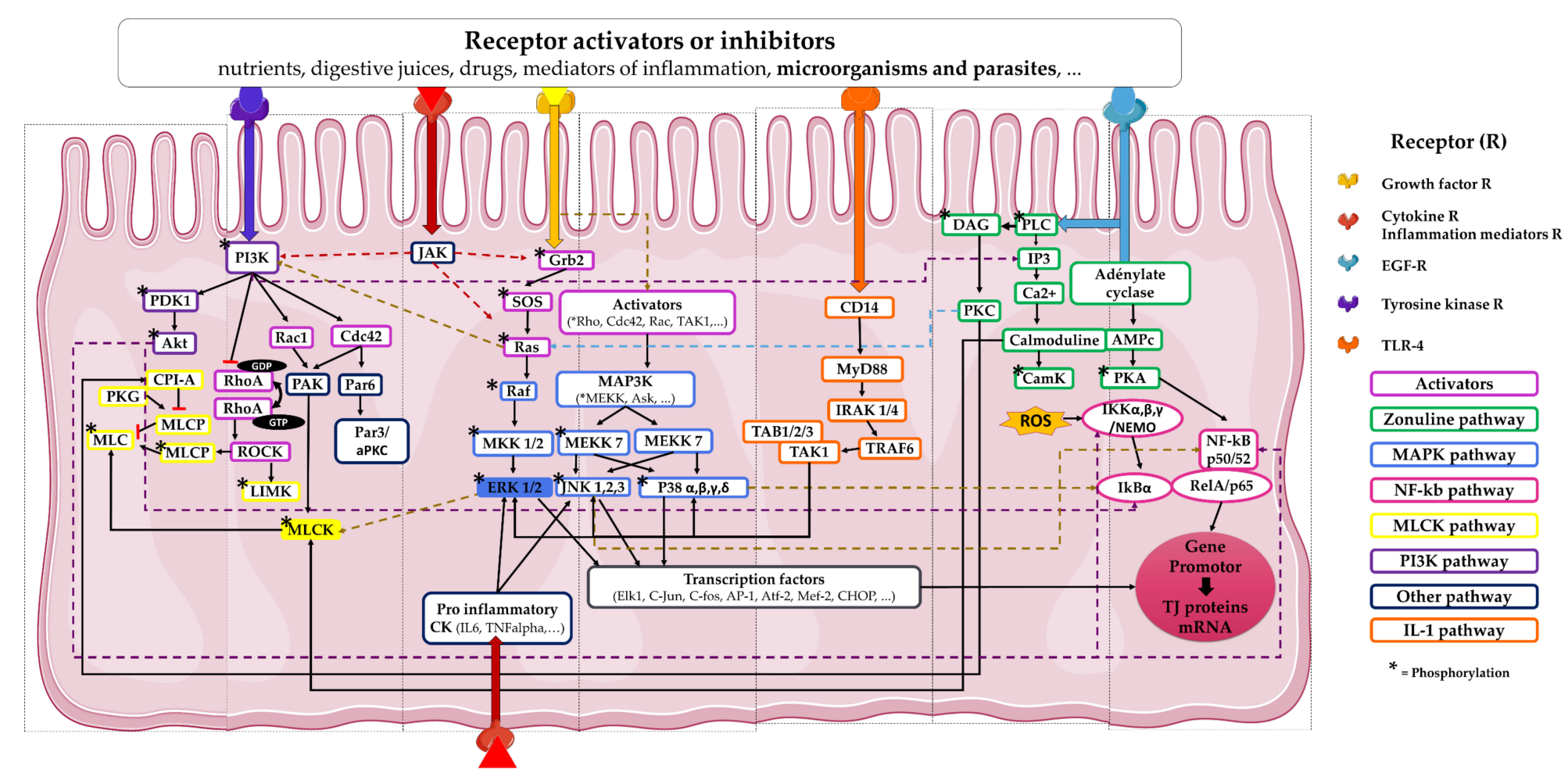

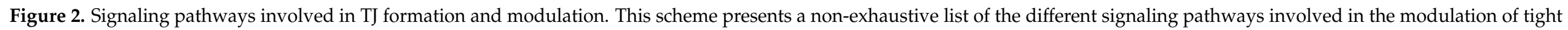

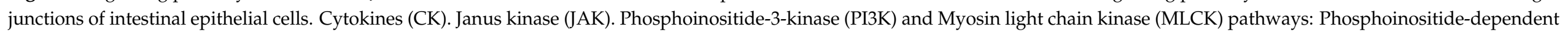

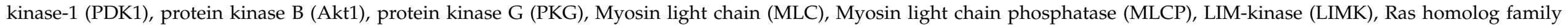

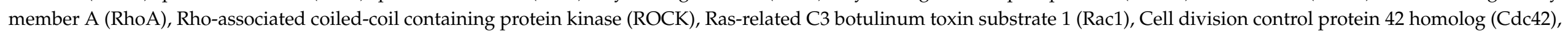

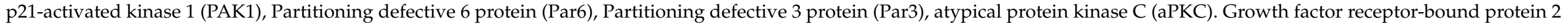

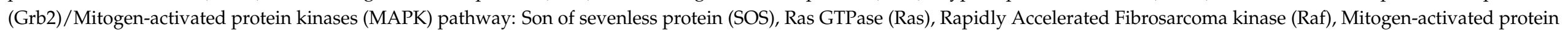

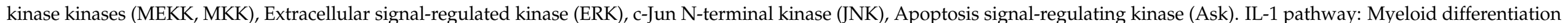

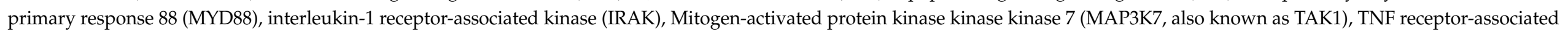

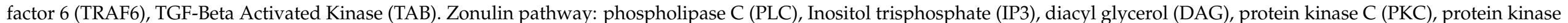

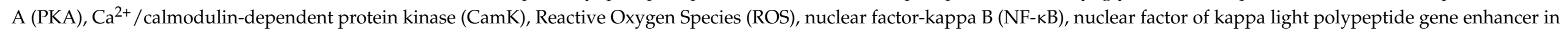

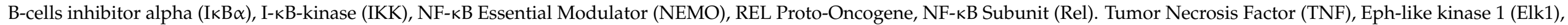
Activator protein 1 (AP-1), myocyte enhancer factor-2 (Mef-2), CCAAT-enhancer-binding protein homologous protein (CHOP). 


\section{Modulation of Tight Junctions by Pathogenic Microbial Agents}

TJs constitute the backbone of the first line of the host defenses by limiting pathogen intrusion from the intestinal lumen to the sterile underlying tissues. Hence, enteropathogenic microbial agents have developed various stratagems to weaken the gut epithelia, exploiting $\mathrm{TJ}$ components to either invade the cells and tissues or promote host and microbial signaling responses that potentiate their invasion [9,46-48]. In both in vivo and in vitro models of enteric infections (i.e., viral, bacterial, fungal, or parasitic), pathogen invasion has been reported to correlate with an increase of the intestine permeability. Table 1 lists studies that correlated the breakdown of gut barrier with a quantitative decrease of one or more proteins belonging to the TJ complex but without specifying the involved mechanisms.

Table 1. Main structural proteins of the tight junction complex in intestinal epithelial cells targeted by pathogens during their infection process.

\begin{tabular}{|c|c|c|c|c|}
\hline \multirow{2}{*}{ TJ Proteins } & \multicolumn{3}{|c|}{ Enteric Pathogens } & \multirow{2}{*}{ Ref. } \\
\hline & Bacteria & Virus & Fungi and Parasites & \\
\hline Occludin & $\begin{array}{c}\text { Aeromonas hydrophila (D) } \\
\text { Campylobacter jejuni (L/D) } \\
\text { Clostridium difficile (L/D) } \\
\text { Clostridium perfringens (L) } \\
\text { Escherichia coli: EAEC (L), EHEC } \\
\text { (L), EPEC (L/D), ETEC (L/D), K12 } \\
\text { (E/Q) } \\
\text { Helicobacter pylori (D) } \\
\text { Listeria monocytogenes (L) } \\
\text { Salmonella typhimurium (Q/L) } \\
\text { Staphylococcus aureus (Q) } \\
\text { Shigella flexneri }(\mathrm{Q} / \mathrm{L}) \\
\text { Vibrio cholerae }(\mathrm{D} / \mathrm{L}) \\
\text { Yersinia enterolitica (Q) }\end{array}$ & $\begin{array}{c}\text { Astrovirus (L) } \\
\text { Coxsackievirus B (L) } \\
\text { Norovirus }(\mathrm{Q}) \\
\text { HIV-1 }(\mathrm{E} / \mathrm{Q}) \\
\text { Rotavirus }(\mathrm{E} / \mathrm{Q} / \mathrm{L})\end{array}$ & $\begin{array}{c}\text { Anisakis simplex (L) } \\
\text { Aspergillus, Penicillium } \\
\text { (D/Q/L) } \\
\text { Blastocystis spp. ST17 } \\
\text { (D) } \\
\text { Candida albicans (Q) } \\
\text { Cryptosporidium parvum } \\
\text { (Q) } \\
\text { Giardia spp. (L) } \\
\text { Toxoplasma gondii (L) }\end{array}$ & {$[34,37,49-86]$} \\
\hline Tricellulin & $\begin{array}{c}\operatorname{EPEC~}(\mathrm{Q}) \\
\text { Yersinia enterolitica }(\mathrm{Q})\end{array}$ & & & {$[80,87]$} \\
\hline Claudin family & $\begin{array}{c}\text { Aeromonas hydrophila (D) } \\
\text { Campylobacter jejuni (L) } \\
\text { Clostridium perfringens (D/L) } \\
\text { Escherichia coli: EAEC (L), EHEC } \\
\text { (L/Q), EPEC (E/D/L), ETEC } \\
\text { (D/L), K12 (E/Q/L) } \\
\text { Helicobacter pylori (D/L) } \\
\text { Listeria monocytogenes (L) } \\
\text { Salmonella typhimurium (L) } \\
\text { Shigella flexneri }(\mathrm{Q} / \mathrm{L}) \\
\text { Yersinia enterolitica }(\mathrm{Q} / \mathrm{L})\end{array}$ & $\begin{array}{l}\text { Astrovirus (L) } \\
\text { HIV-1 (E/Q) } \\
\text { Rotavirus (L) } \\
\text { Norovirus (Q) }\end{array}$ & $\begin{array}{c}\text { Aspergillus and } \\
\text { Penicillium }(\mathrm{D} / \mathrm{L} \mathrm{Q}) \\
\text { Candida albicans }(\mathrm{Q}) \\
\text { Cryptosporidium parvum } \\
\text { (Q) } \\
\text { Entamoeba histolytica }(\mathrm{L}) \\
\text { Giardia spp. }(\mathrm{L})\end{array}$ & $\begin{array}{c}{[49,50,54,60,63,} \\
67-73,75,78,80,84 \\
85,88-105]\end{array}$ \\
\hline JAM-A & & Rotavirus & Candida albicans (Q) & {$[84,106]$} \\
\hline $\begin{array}{c}\text { Zonula } \\
\text { occludens 1-3 }\end{array}$ & $\begin{array}{c}\text { Aeromonas hydrophila }(\mathrm{D}) \\
\text { Clostridium difficile (D/L) } \\
\text { Escherichia coli: EAEC (L), EHEC } \\
\text { (L), EPEC (E/D/L), ETEC (D/L), } \\
\text { K12 (E/Q/L) } \\
\text { Helicobacter pylori }(\mathrm{L}) \\
\text { Salmonella typhimurium (Q/L) } \\
\text { Staphylococcus aureus }(\mathrm{Q}) \\
\text { Shigella flexneri }(\mathrm{Q} / \mathrm{L}) \\
\text { Vibrio cholerae }(\mathrm{L}) \\
\text { Yersinia enterolitica }(\mathrm{Q})\end{array}$ & $\begin{array}{c}\text { Adenovirus (L/Q) } \\
\text { Astrovirus (L) } \\
\text { Coxsackievirus B } \\
\text { HIV-1 (E/L) } \\
\text { Rotavirus (L) }\end{array}$ & $\begin{array}{c}\text { Anisakis simplex }(\mathrm{L}) \\
\text { Aspergillus and } \\
\text { Penicillium }(\mathrm{D} / \mathrm{Q} / \mathrm{L}) \\
\text { Blastocystis spp. ST17 } \\
\text { (D/L) } \\
\text { Candida albicans }(\mathrm{Q}) \\
\text { Cryptosporidium } \\
\text { andersoni }(\mathrm{L}) \\
\text { Cryptosporidium paroum } \\
\text { (Q) } \\
\text { Entamoeba histolytica }(\mathrm{D}) \\
\text { Giardia spp. (D/Q/L) }\end{array}$ & $\begin{array}{c}{[34,37,49-54,58-} \\
62,64- \\
69,71,73,74,77- \\
79,81,82,85,92- \\
94,102,107-115]\end{array}$ \\
\hline
\end{tabular}


Studies, listed here, mainly reported TJ protein fitness based on Western blotting and microscopy analyses during IEC infection without including involved mechanism characterization. Different outcomes of TJ proteins were reported: modification of cell distribution (L), modification of gene expression (E), variation of protein quantity $(\mathrm{Q})$, and dissociation +/ - degradation of the TJ complex (D). Enteroaggregative Escherichia coli (EAEC), Enterohemorrhagic Escherichia coli (EHEC), Enteropathogenic Escherichia coli (EPEC), Enterotoxigenic Escherichia coli (ETEC). In the gut, TJ modulation occurs through specific microbial effector molecules that are bound to their membrane, capsid, or cell wall, or secreted in the intestinal lumen, or, for gram negative bacteria, injected into the cytoplasm of the host cells using type III secretion systems (T3SS) [88,89,116-118]. These effectors can act directly upon constitutive TJ proteins through either their lytic activity (i.e., proteases, lipases, phosphatases) leading to the degradation of TJs or through specific binding allowing the disengagement of TJ proteins from the junctional complex (Table 1). Pathogenic factors can also trigger cell signaling pathways involved in both TJs and cytoskeleton modulation by either inducing up- or down-regulation of gene expression or post-transcriptional events such as phosphorylation. Finally, pro-inflammatory and/or oxidative stresses of IECs resulting from infection can potentiate dysregulation of the TJ complex.

In the following sections, we provide an overview of the different microbial strategies aimed at invading the digestive mucosa by targeting the TJ complex (Figure 3 and Table 2).

Table 2. Examples of mechanisms involved in TJ modulation by pathogens that induces intestinal barrier breakdown permeability.

\begin{tabular}{|c|c|c|c|c|}
\hline Pathogens & $\begin{array}{l}\text { Host Cell Receptor }(\mathrm{H}) \\
\text { and/or Pathogens } \\
\text { Elements }(\mathrm{P}) \text { Involved }\end{array}$ & $\begin{array}{l}\text { Activated Host } \\
\text { Pathways in IEC }\end{array}$ & $\begin{array}{c}\text { Junctions and Cytoskeleton } \\
\text { Modeling }\end{array}$ & Ref. \\
\hline \multicolumn{5}{|c|}{ Viruses } \\
\hline Adenovirus & CAR cell receptor $(\mathrm{H})$ & Nc & $\mathrm{ZO}-1(\mathrm{p} \downarrow)(\mathrm{L})$ & [108] \\
\hline Astrovirus & Capsid protein $(\mathrm{P})$ & $\mathrm{Nc}$ & $\begin{array}{l}\text { Occludin, claudin, } \mathrm{ZO}-1(\mathrm{~L}) \\
\text { Actin rearrangement }\end{array}$ & {$[51]$} \\
\hline Coxsackievirus B & $\begin{array}{l}\text { Epithelial DAF }(\mathrm{H}) \\
\text { CAR cell receptor }(\mathrm{H}) \\
\text { Viral particles }(\mathrm{P})\end{array}$ & Rho GTPases & $\begin{array}{c}\mathrm{ZO}-1(\mathrm{p} \downarrow)(\mathrm{L}) \\
\text { Occludin }(\mathrm{L}) \\
\text { Actin rearrangement }\end{array}$ & {$[61,62,108]$} \\
\hline \multirow{2}{*}{ HIV-1 } & $\begin{array}{l}\text { TLRA-MD2-CD14 }(\mathrm{H}) \\
\text { Tat protein }(\mathrm{P})\end{array}$ & $\begin{array}{l}\text { NF-kB (IL-18) } \\
\text { MLCK }\end{array}$ & $\begin{array}{l}\text { Occludin, claudin }(\mathrm{p} \downarrow) \\
\text { F-actin }(\mathrm{p} \downarrow)\end{array}$ & [119] \\
\hline & gp120 (P) & $\mathrm{Nc}$ & $\begin{array}{l}\text { Occludin, claudins } 1-2, \mathrm{ZO}-1 \text { (p } \\
\text { and } \mathrm{g} \downarrow \text { ), ZO-1 (L) }\end{array}$ & {$[71]$} \\
\hline Rotavirus & $\mathrm{Nc}$ & PKA & $\begin{array}{c}\text { Occludin (g } \downarrow \text { ), phosphorylated } \\
\text { form ( } \mathrm{p} \downarrow)\end{array}$ & {$[58]$} \\
\hline \multicolumn{5}{|c|}{ Bacteria } \\
\hline Aeromonas hydrophila & Bacterial aerolysin $(\mathrm{P})$ & $\begin{array}{c}\text { Intracellular } \mathrm{Ca}^{2+} \text { influx } \\
\text { MLCK }\end{array}$ & $\begin{array}{l}\text { Occludin, claudins } 1 / 4 / 5, \mathrm{ZO}-1(\mathrm{~L}) \\
\text { F-actin condensation }\end{array}$ & {$[54]$} \\
\hline Bacteroïdes fragilis & Fragilysin $(\mathrm{P})$ & $\mathrm{Nc}$ & $\begin{array}{l}\text { E-cadherin and F-actin } \\
\text { disassembly }\end{array}$ & {$[120-122]$} \\
\hline Campylobacter concisus & Zot toxin $(\mathrm{P})$ & $\begin{array}{c}\text { NK-кB } \\
\text { Pro-inflammatory } \\
\text { cytokines }\end{array}$ & $\begin{array}{l}\mathrm{ZO}-1(\mathrm{~g} \downarrow) \\
\text { Cytoskeleton rearrangement }\end{array}$ & [107] \\
\hline \multirow{2}{*}{ Campylobacter jejuni } & Proteases $(\mathrm{P})$ & $\begin{array}{l}\text { None. } \\
\text { Direct action }\end{array}$ & Occludin and E-cadherin (L) & {$[55]$} \\
\hline & $\begin{array}{l}\text { Serine protease HtrA } \\
(\mathrm{P})\end{array}$ & $\begin{array}{l}\text { None. } \\
\text { Direct action }\end{array}$ & Occludin (L) & {$[56]$} \\
\hline
\end{tabular}


Table 2. Cont.

\begin{tabular}{|c|c|c|c|c|}
\hline Pathogens & $\begin{array}{l}\text { Host Cell Receptor }(\mathrm{H}) \\
\text { and/or Pathogens } \\
\text { Elements (P) Involved }\end{array}$ & $\begin{array}{l}\text { Activated Host } \\
\text { Pathways in IEC }\end{array}$ & $\begin{array}{c}\text { Junctions and Cytoskeleton } \\
\text { Modeling }\end{array}$ & Ref. \\
\hline Clostridium difficile & Toxins $\mathrm{A}$ and $\mathrm{B}$ & Rho GTPases & $\begin{array}{c}\text { Occludin, } \mathrm{ZO}-1 / 2, \text { E-cadherin }(\mathrm{L}), \\
\text { Actin rearrangement }\end{array}$ & [37] \\
\hline \multirow{3}{*}{ Clostridium perfringens } & $\mathrm{Nc}$ & CpAL system & Occludin, claudin $3(\mathrm{~L})$ & [72] \\
\hline & CPE Enterotoxin $(\mathrm{P})$ & Binding to claudins $3 / 4$ & Claudin $4(\mathrm{p} \downarrow)(\mathrm{L})$ & [90] \\
\hline & Delta toxin $(\mathrm{P})$ & ADMA10 & E-cadherin $(\mathrm{p} \downarrow)$ & [123] \\
\hline E. coli EAEC & $\mathrm{Nc}$ & AAF/II action & Occludin, claudin1, ZO-1 (L) & [73] \\
\hline E. coli EHEC & Shiga/vero toxins $(\mathrm{P})$ & MLCK & $\begin{array}{l}\text { Occludin, claudin } 3, \mathrm{ZO}-1 \text { (L) } \\
\text { Claudin } 2(\mathrm{p} \downarrow)\end{array}$ & {$[74,75]$} \\
\hline \multirow{3}{*}{ E. coli EPEC } & EspG1 effector $(\mathrm{P})$ & $\mathrm{Nc}$ & Tricellulin $(\mathrm{p} \downarrow)$ & [87] \\
\hline & $\begin{array}{l}\text { EspF, EspI, EspG, Map, } \\
\text { CNF-1, Tir effectors (P) }\end{array}$ & MLCK & $\begin{array}{l}\text { Occludin, claudin } 1 \text { and } \mathrm{ZO}-1 \text { (L) } \\
\text { Actin-myosin ring contraction }\end{array}$ & $\begin{array}{c}{[88,89,97-} \\
100]\end{array}$ \\
\hline & $\begin{array}{l}\text { Extracellular vesicles } \\
\text { and secreted factors }(\mathrm{P})\end{array}$ & Nc & $\begin{array}{c}\text { Occludin, claudins, ZO-1/2 (g } \downarrow \text { ) } \\
\text { Occludin, ZO-1 (L) } \\
\text { F-actin rearrangement }\end{array}$ & [59] \\
\hline E. coli ETEC & Stb toxin $(\mathrm{P})$ & $\mathrm{Nc}$ & Occludin, claudin $1, \mathrm{ZO}-1$ (L) & {$[60]$} \\
\hline \multirow{3}{*}{ Helicobacter pylori } & $\begin{array}{l}\text { VacA and CagA factors } \\
\text { (P) }\end{array}$ & $\mathrm{Nc}$ & $\mathrm{ZO}-1(\mathrm{~L})$ & [109] \\
\hline & Unspecified & MLCK & Occludin, claudins $4 / 5(\mathrm{~L})$ & [76] \\
\hline & $\begin{array}{c}\text { IL-R1 receptor }(\mathrm{H}) \\
\text { Bacteria contact }(\mathrm{P} / \mathrm{H})\end{array}$ & ROCK activation & Claudins 1/4, ZO-1 (L) & {$[101,102]$} \\
\hline Listeria monocytogenes & $\begin{array}{l}\text { Hsp60 cell receptor }(\mathrm{H}) \\
\text { LAP protein }(\mathrm{P})\end{array}$ & $\begin{array}{c}\text { NF-kB, MLCK } \\
\text { Secretion TNF } \alpha \text { IL6 }\end{array}$ & Occludin, claudin 1, E-cadherin (L) & [63] \\
\hline \multirow{2}{*}{ Salmonella typhimurium } & $\begin{array}{l}\text { SopB, SopE, SopE2, } \\
\text { SipA factors }(P)\end{array}$ & $\begin{array}{l}\text { Rho GTPase } \\
\text { IL-8 }\end{array}$ & $\begin{array}{l}\text { Occludin, ZO-1 (L) } \\
\text { Actin (L) }\end{array}$ & {$[66]$} \\
\hline & Nc & PKC & $\begin{array}{l}\text { ZO-1 and pZO-1 (p } \downarrow) \\
\text { Claudin } 1, \mathrm{ZO}-2(\mathrm{~L})\end{array}$ & [77] \\
\hline Staphylococcus aureus & Alpha toxin $(\mathrm{P})$ & $\mathrm{Nd}$ & Occludin, ZO-1/3, E-cadherin ( $\mathrm{p} \downarrow)$ & [79] \\
\hline \multirow{3}{*}{ Shigella flexneri } & $\begin{array}{l}\text { T3SS protein injection } \\
\text { effector }(\mathrm{P})\end{array}$ & $\mathrm{Nd}$ & 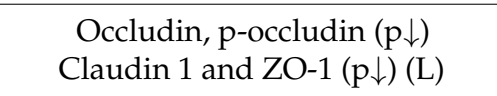 & [67] \\
\hline & SepA $(P)$ & $\begin{array}{l}\text { LIMK1 }(g \downarrow) \\
\text { Cofilin }\end{array}$ & Actin modification & [124] \\
\hline & $\mathrm{Nd}$ & ERK1/2 & Claudins 2/4 (L) & [91] \\
\hline \multirow[b]{2}{*}{ Vibrio cholerae } & $\begin{array}{l}\text { Hemagglutinin } \\
\text { protease HA/P (P) }\end{array}$ & $\mathrm{Nd}$ & $\begin{array}{l}\text { Occludin, } \mathrm{ZO}-1(\mathrm{~L}) \\
\text { Actin rearrangement }\end{array}$ & {$[52,53]$} \\
\hline & $\begin{array}{l}\mathrm{PAR}_{2} \text { receptor }(\mathrm{H}) \\
\text { Zot }(\mathrm{P})\end{array}$ & $\begin{array}{l}\text { PLC } \\
\text { PKC }\end{array}$ & $\begin{array}{l}\text { Occludin, } \mathrm{ZO}-1(\mathrm{~L}) \\
\text { Myosin phosphorylation } \\
\text { Actin polymerization }\end{array}$ & {$[34,125]$} \\
\hline Yersinia enterolitica & $\mathrm{Nd}$ & MAPK (JNK) & $\begin{array}{c}\text { Claudins } 2 / 3 / 8 / 10, \mathrm{ZO}-1(\mathrm{p} \downarrow) \\
\text { Claudins } 3 / 4 / 8(\mathrm{~L})\end{array}$ & [126] \\
\hline & & Fungi and parasites & & \\
\hline \multirow{2}{*}{$\begin{array}{l}\text { Aspergillus and } \\
\text { Penicillium }\end{array}$} & Ochratoxin (P) & $\begin{array}{c}\text { MLCK } \\
\text { ROS response } \\
{\left[\mathrm{Ca}^{2+}\right] c \text { increase }}\end{array}$ & $\begin{array}{l}\text { Claudin 1, ZO-1 (p } \downarrow \text { ) } \\
\text { Occludin and ZO-1 (L) }\end{array}$ & {$[65,94]$} \\
\hline & $\begin{array}{c}\text { DEP-1 cellular protein } \\
(\mathrm{H}) \\
\text { Patulin }(\mathrm{Pat})(\mathrm{P})\end{array}$ & $\begin{array}{c}\text { DEP-1 }(\mathrm{g} \downarrow) \text { PPAR } \gamma \\
\text { protein }(\mathrm{p} \downarrow) \\
\text { p-MLC-2 }(\mathrm{p} \uparrow)\end{array}$ & $\begin{array}{l}\text { Occludin, ZO-1 (p } \downarrow) \\
\text { Claudin } 4 \text { (L) }\end{array}$ & $\begin{array}{c}{[82,93,110,} \\
127]\end{array}$ \\
\hline
\end{tabular}


Table 2. Cont.

\begin{tabular}{|c|c|c|c|c|}
\hline Pathogens & $\begin{array}{l}\text { Host Cell Receptor }(\mathrm{H}) \\
\text { and/or Pathogens } \\
\text { Elements }(\mathrm{P}) \text { Involved }\end{array}$ & $\begin{array}{l}\text { Activated Host } \\
\text { Pathways in IEC }\end{array}$ & $\begin{array}{c}\text { Junctions and Cytoskeleton } \\
\text { Modeling }\end{array}$ & Ref. \\
\hline \multirow{2}{*}{ Blastocystis spp. } & $\begin{array}{l}\text { Galactose residues on } \\
\text { cell surface }(\mathrm{H})\end{array}$ & $\mathrm{Nd}$ & Occludin, ZO-1 (p $\downarrow)$ & [83] \\
\hline & Cathepsin B (P) & $\begin{array}{l}\text { ROCK } \\
\text { p-MLC }\end{array}$ & $\mathrm{ZO}-1(\mathrm{~L})$ & {$[128,129]$} \\
\hline \multirow{2}{*}{ Candida albicans } & $\mathrm{Nd}$ & MAPK & $\begin{array}{l}\text { Occludin, claudins } 1 / 3 / 4 \text {, JAM-A } \\
\qquad(\mathrm{p} \downarrow)\end{array}$ & [84] \\
\hline & Heat-killed yeasts $(\mathrm{P})$ & NLRP3/NLRP6 & Occludin and ZO-1 (p/g $\downarrow)$ & [64] \\
\hline \multirow{3}{*}{ Entamoeba histolytica } & Cystein proteinases $(\mathrm{P})$ & $\mathrm{Nd}$ & $\begin{array}{c}\mathrm{ZO}-1(\mathrm{p} \downarrow) \\
\mathrm{ZO}-1 / \mathrm{ZO}-2(\mathrm{~L})\end{array}$ & [112] \\
\hline & $\begin{array}{l}\text { Secreted Prostaglandin } \\
\text { E2 }(\mathrm{P})\end{array}$ & $\mathrm{Nd}$ & Claudin $4(\mathrm{~L})$ & [104] \\
\hline & $\begin{array}{l}\text { rEhCP112 proteinase } \\
(\mathrm{P})\end{array}$ & Direct interaction & Claudins $1 / 2$ & [130] \\
\hline Giardia spp. & Nc & MLCK & $\begin{array}{c}\mathrm{ZO}-1(\mathrm{~L}) \\
\text { Actin rearrangement }\end{array}$ & $\begin{array}{r}{[86,105} \\
113,114]\end{array}$ \\
\hline Toxoplasma gondii & $\begin{array}{l}\text { Extracellular loops of } \\
\text { occludin }(\mathrm{H})\end{array}$ & Direct interaction & Occludin (L) & {$[57,131]$} \\
\hline
\end{tabular}

Studies, listed here, were conducted only in enteric infection models of murine IEC (IEC-6, m-IC), porcine IEC (IPEC-J2) or human IEC (Caco-2, C2BBe1, HT29, HT29/B6, T84, HCT116, HCT-8) and gastric (NCI-N87 and their derived cell model HGE-20) epithelial cells. Protein modulation is documented with (L) when associated with localization change or with arrows illustrating protein cellular amount or gene expression increase or decrease respectively $(\mathrm{p} \uparrow)$, $(\mathrm{p} \downarrow)$, or $(\mathrm{g} \downarrow)$. Nc: Non-characterized. AAF-II: Aggregation Adherence Fimbriae II, CAR: Coxsackievirus and Adenovirus Receptor, CpAl: Clostridium perfringens Arg-like system, DAF: Decay-Accelerating Factor, HA/P: Hemagglutinin Protease, htrA: high temperature requirement protein A, InlC: Internalin C, LAP: Listeria Adhesion Protein, MLCK: Myosin Light Chain Kinase, PAR2: Protease activated receptor 2, PKA: Protein Kinase A, Sop: Salmonella outer protein, SPI: Salmonella Pathogenicity Island1, Stb: Escherichia coli heat stable toxin b, Tcd: Clostridium difficile toxin, ZO: Zonula occludens, Zot: ZO toxin.

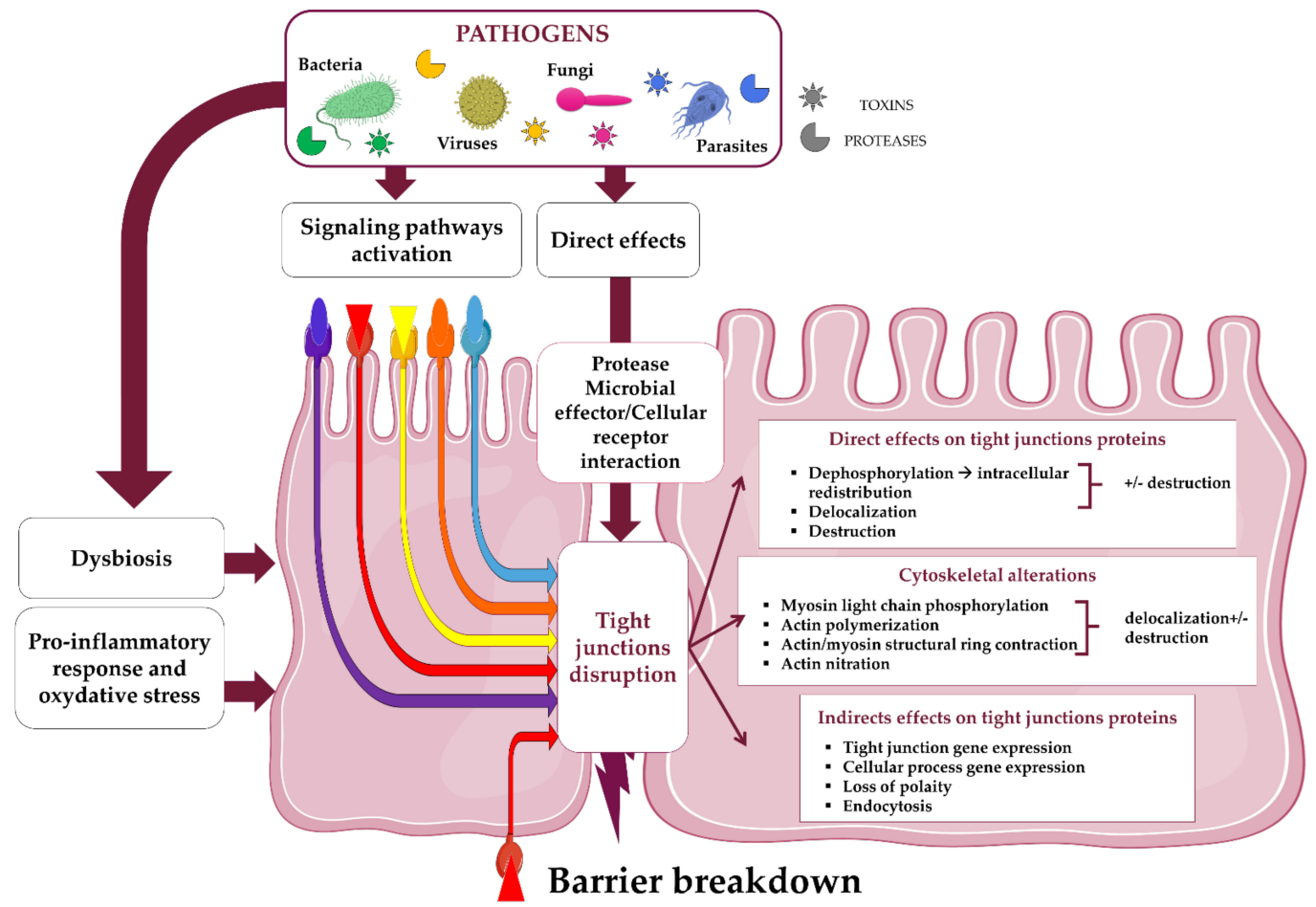

Figure 3. Role of tight junction interactions in pathogenesis of microorganisms. The compromise of TJ integrity involved different strategies developed by microbial pathogens. Microorganisms or their components directly impact the TJ organization 
through lytic activity or binding on TJ proteins that interfere on their connection to the TJ complex. Interactions between microbial effectors with IEC receptors lead in the activation of different signaling pathways intimately linked and interacting with each other. As these pathways are involved in many other cellular process (proliferation, oncogenesis, cell cycle, differentiation ... ), their activation contributes to the host response concomitantly to TJ disruption. Besides, the loss of permeability related to $\mathrm{TJ}$ appears as a consequence of a deleterious host response against its aggression though excessive pro-inflammatory cytokine production and endogenous biosynthesis of nitric oxide (NO).

\subsection{Action of Microbial Toxins on the IECs' Cytoskeleton}

Some microorganisms use effector toxins that destabilize the architecture of the cytoskeleton or promote contraction of the myosin/actin ring, through the activation of MLCK or Rho GTPases pathways, both inducing a subsequent TJ disruption [49-51,132-135].

Viral enterotoxins induce the rearrangement of F-actin filaments and/or microtubules, leading to TJ disruption as exemplified with enteric viruses such as Astrovirus or Rotavirus [49-51]. The mechanisms involved in permeability increase during these viral infections has not yet been elucidated.

In bacteria, the glucosyltransferase activity of the secreted toxins $A$ and $B$ of Clostridium difficile activates both isoforms $\alpha$ and $\beta$ of the cellular kinase PKC, leading to the RhoA glycosylation in T84 IECs [136]. The resulting inactivation of the Rho GTPases allows actin rearrangement and the dissociation of the actine/ZO-1 complex, followed by the subsequent remove of occludin, $\mathrm{ZO}-1$ and 2 from the junctional plaque $[37,134]$. During Salmonella infections, the pathogenesis process is mainly associated with the injection of the secreted proteins SopB, SopE, SopE2, and SipA in the host cell cytoplasm, that also activate Rho GTPase and PKC pathways [116,117]. Furthermore, the entero-pathogenic Escherichia coli (EPEC) has been reported to induce actin/myosin ring contraction and subsequent TJ disruption through calcium- and MLCK-dependent processes triggered by injected T3SS factors (i.e., Tir, EspB, EspF, EspH, and Mad) $[88,89,118]$. Another example of bacterial toxin targeting the actin/myosin ring has been reported for the zonula occludens toxin (Zot) of Vibrio cholerae that acts by activating the EGF/PAR 2 receptor, leading to a cascade of phosphorylation initiated by phospholipase C and then PKC [33,34,137-139]. In fine, this results in the contraction of the actin/myosin ring associated with the displacement of the junctional complex ZO-1/ZO-2 from the membrane to the cytosol [34].

Similar approaches have been observed in fungi belonging to Aspergillus and Penicillium genera [140]. For instance, fungal metabolites such as cytochalasin D or the mycotoxin patulin have been reported to activate the MLCK regulatory pathway, leading to the disruption of F-actin filaments or the inhibition of its polymerization. Subsequently, the TJ organization is impaired along with cellular processes such as cellular endocytosis [24,127].

\subsection{Direct Interaction of the Microbial Agents with TJ Proteins}

Pathogens can target TJ proteins using virulence factors either localized on the pathogen outermost layer (i.e., cell wall or capsid/envelop), or secreted directly or through vesicles transported in the intestinal lumen. In this context, two major mechanisms have been observed: (i) a disorganization of the TJ network involving microbial components displaying lipase or protease activities on TJ complex or (ii) a direct interaction of microbial effectors with one or several TJ protein(s), leading to its/their detachment or relocation from the junctional complex to other cellular compartments.

Many pathogenic agents secrete enterotoxins exhibiting a protease activity, as reported for the fragylisin enterotoxin (BFT) of Bacteroïdes fragilis, the aerolysin of Aeromonas hydrophila, the hemagglutinin protease $(\mathrm{Ha} / \mathrm{P})$ of Vibrio cholerae and the serine protease High temperature requirement protein A (HtrA) of Campylobacter jejuni [52-56,118,120$122,134,141-143]$.

Whether they are secreted or not, microbial effectors can directly interact specifically with host TJ proteins. Thereby, the Clostridium perfringens enterotoxin (CPE) binds to claudins 4 leading to its cytosolic localization and destruction [90]. Similarly, during digestive amebiasis, interaction of the cysteine proteinase rEhCP112 of Entamoeba histolytica with claudins 1 and 2 leads to their degradation and cytosolic localization [130]. In the same way, 
Toxoplasma gondii co-localizes with the extracellular loops of the occludin during invasion of IECs. This physical interaction induces changes in the distribution and partitioning of occludin [57]. However, the molecular mechanism driving these events as well as the parasite effector molecules involved remain to be clarified.

\subsection{Microbial Modulation of Signaling Pathways Involved in TJ Organization}

Microbial agents can modulate signaling pathways involved in the structural organization of the TJ complex, leading to (i) changes in gene expression encoding TJ proteins or (ii) post-transcriptional events (e.g., level and site of phosphorylation of TJ proteins, protein trafficking) involved in the localization and partitioning of the proteins from the TJs to the cytoplasm (Table 2). In fine, all these events favor an increase in IECs' permeability.

As specified in Section 3.1, the MLCK and Rho signaling pathways are key pathways for TJ formation and modulation also in various models of infection with the aim to increase gut permeability (Table 2).

The PKA signaling pathway has been reported as a possible target for enteric pathogens that consequently increase gut permeability. For instance, binding of the enteropathogenic Escherichia coli (EPEC) heat-stable enterotoxin A (STa) to the extracellular domains of the guanylate cyclase receptor (GC-C) catalyzes cGMP formation. This complex further activates the cAMP-dependent-protein kinase A (PKA) leading to, among others, a dephosphorylation of the occludin protein and its subsequent redistribution from the membrane to the cytosol [142,144-146]. Similarly, during Rotavirus infection of IECs, a specific decrease in the occludin protein level at the TJ complex is reported as the result of the downregulation of occludin gene transcription with regulatory signals involving both Rp-cyclic AMP and PKA pathways [58].

Microbial components through the modulation of the MAPK pathway can alter TJ organization (Table 2). During Shigella flexneri or EPEC infection, the dysfunction of the gut barrier results from changes in the level of phosphorylation of claudin- 2 and -4 , occludin and ZO-1 proteins, through ERK1/2 pathway $[59,91]$. However, other kinases belonging to the MAPK pathway may be specifically involved in bacterial TJ alteration, as observed in a Yersinia enterolitica model of IECs infection. In this model, the decrease in claudin 8 levels correlates with the phosphorylation of JNK but not of the other MAP kinases [92].

Signaling pathways are diverse and numerous. They notably act jointly in TJ regulation, some of them probably being concomitantly targeted by probiotics to prevent $\mathrm{TJ}$ alteration induced by pathogens (Table 3). However, in most of the studies investigating modulation of the TJ complex by pathogens, the sequence of the signaling cascade is partially investigated, leaving numerous gaps in our knowledge of the precise mechanisms involved in these modulatory events. Nevertheless, the molecular mechanisms drawing the breakdown of the intestinal barrier associated with $\mathrm{TJ}$ alteration have been better characterized in few infection models.

Table 3. Tight junction protection by probiotics preventing breakdown permeability induced during infections.

\begin{tabular}{|c|c|c|c|}
\hline Probiotics & Pathogens & TJ Protein Modulation & Ref. \\
\hline Lactobacillus acidophilus & Salmonella typhimurium & Modulation of 26 genes linked to TJ integrity & [147] \\
\hline Saccharomyces boulardii & Salmonella typhimurium & Interference on Rho GTPase activation & [148] \\
\hline Escherichia coli Nissle 1917 & Campylobacter jejuni & Increase of gene expression of the claudins $2 / 4 / 11$ & [149] \\
\hline Lactobacillus reuteri (LR1) & & Inactivation of MLCK pathway & [150] \\
\hline $\begin{array}{l}\text { Lactobacillus plantarum (GRI-2) } \\
\text { Lactobacillus rhamnosus (LG6) } \\
\text { Lactobacillus fermentum (FA-1) } \\
\text { Lactobacillus salivarius (GPI-1) }\end{array}$ & EPEC & $\begin{array}{l}\text { Maintenance of membrane localization and gene } \\
\text { expression of ZO-1, occludin, claudins } 1 / 4 \text { and JAM-A }\end{array}$ & [151] \\
\hline Bacillus subtilis (CW14) & Fungal ochratoxin A & Prevention of ZO-1 destruction & [94] \\
\hline Bacillus clausii & Rotavirus & Overexpression of occludin and $\mathrm{ZO}-1$ proteins & [152] \\
\hline
\end{tabular}


Thereby, the example of the action of zonula occludens toxin (Zot) from Vibrio cholerae upon IECs' permeability highlights the complexity of the TJ regulatory network involved during microbial infection. The synthetic peptide AT-1002, corresponding to the C-terminal domain of Zot, induces alteration of TJs. This results from the activation of the MAPK pathway (JNK) which ultimately leads to the phosphorylation of the tyrosine residues of ZO-1 and its remove from the TJ plaque together with F-actin rearrangement $[125,153]$. Besides, the phospholipase C/PKC pathway is also involved as suggested by the binding of its associated EGF/PAR 2 receptor to Zonulin, a eukaryotic analogue of Zot. Its activation ends with an increase in the intracellular calcium concentration, a further contraction of the actin/myosin ring and finally the shifting of the junctional complex ZO-1/ZO-2 from the membrane to the cytosol $[33,34,139]$. In addition, other bacterial toxins, including the heat-stable toxin b (Hst b) from enterotoxigenic Escherichia coli or the Zot from Campylobacter concisus, display partial sequence homology with the active domain of Zot from Vibrio and potentially share regulatory pathways involved in modulating TJ complex [60,107].

Another example of the cooperation of several pathogen-targeted cellular pathways has been described during IECs treatment with patulin. As presented above, this mycotoxin activates the MLCK regulatory pathway. In parallel, it decreases expression of both the density-enhanced phosphatase-1 (DEP-1) and Peroxisome ProliferAtor Receptor gamma (PPAR $\gamma$ ), the latter controlling DEP-1 expression [93]. The subsequent hyper-phosphorylation of claudin 4 protein then induces disturbances in claudin-4/ZO-1 interactions, hence favoring their release from the TJ complex [93].

Many viruses, including Adenovirus, Coxsackievirus, Hepatitis C virus, and Rotavirus, have been reported to target extracellular domains of the TJ constitutive proteins [46]. The cellular receptor within the enterocyte TJ complex has been indeed identified for at least three viruses including (i) Rotavirus attaching to the JAM protein and (ii) Coxsackievirus and Adenovirus that bind to Coxsackievirus and Adenovirus receptor (CAR), a transmembrane protein associated with ZO-1 either directly or through intermediary proteins, namely MAGI-1 and MUPP1 [106,154]. However, the following events promoting the disorganization of TJs and the resulting decrease in IECs' permeability remain to be specified, except for Coxsackievirus B for which molecular mechanisms have been detailed following its binding to CAR. Indeed, during IECs' infection, Coxsackievirus B does not induce major TJ reorganization, but stimulates the specific internalization of occludin within macropinosomes [61]. Concomitantly, this virus interacts with the intestinal epithelial protein DAF (Decay-Accelerating Factor) leading to its redistribution into lipid rafts. This DAF localization is followed by the successive activation of the tyrosine kinase c-Ab1 and the Rho GTPases Rac. The subsequent actin remodeling allows the transport of DAF bound particles into TJ complex. All these events are required for the viral entry. [61,62,108].

Finally, most of the pathways cited here are not restricted to a single cellular process. Indeed, for instance, activation of the MLCK pathway promotes an increase in IECs' permeability, as a consequence of both the modulation of the TJ structure and intracellular $\mathrm{Ca}^{2+}$ influx. This was exemplified with the bacterial aerolysin from Aeromonas hydrophila that has been shown to target the MLCK signaling cascade, promoting the disassembly of claudins 1 and 4 concomitantly to an increase in the intracellular influx of $\mathrm{Ca}^{2+}$, both mechanisms being necessary for disorganization of the $\mathrm{TJ}$ complex and the subsequent decrease in IEC permeability [54].

\section{Indirect Modulation of the TJs Consequently to the Host Response Facing Infection}

Finally, the modulation of intestinal TJ integrity can also result from IECs deleterious inflammatory response facing the infection process. Altered intestinal TJ integrity has been reported to result from pro-inflammatory events involving cytokines such as IL-1 $\beta$, IL-4, IL-6, IL-13, and TNF- $\alpha /$ IFN $\gamma$ secreted by IECs, that subsequently activate regulatory pathways linked to the TJ complex [24,155-157]. Some of these cytokines, including IL-1 $\beta$ and IL-18, are secreted following activation of the inflammasome pathway during IECs' infection [158]. 
Focusing on the IL-18 pathway, during IECs' infection by HIV-1, the transactivator HIV Tat protein binds to TLR4-MD2-CD14 epithelial complex, activating the NF- $\mathrm{KB}$ pathway. Consequently, mature IL-18 is released by IECs that subsequently induces an increase of permeability by (i) decreasing and disrupting both TJs and AJs and (ii) altering cytoskeleton. In parallel, the treatment of the IECs with IL-18 decrease the expression of both claudin-2 and occludin as determined by Western blot analyses. These observations correlate with an increase in the expression of MLCK and phosphorylation of MLC by ROCK [119].

Regarding the IL-6 pathway, interaction of the secreted Listeria adhesion protein (Lap) to the host cell Hsp60 receptor promotes activation of the NF-kB pathway [63]. This activation induces the MLCK-mediated opening of the TJs, associated with a concomitant upregulation of pro-inflammatory TNF $\alpha$ and IL-6 [63]. These observations suggest that the disorganization of the TJ complex may associate an inflammatory burst that will secondarily accentuate the decrease in IECs' permeability. For instance, the release of IL6 by IEC induced by LPS has been reported to decrease membrane integrity $[159,160]$. Moreover, interestingly, in Gram-negative bacterial infection models, the release of lipopolysaccharide (LPS) has been shown to decrease the transcriptional expression of occludin and a cytosolic localization of claudin 1 [161]. However, LPS-induced secretion of IL-6 upon TJ integrity has not been investigated.

During interaction of IEC with live or heat-killed Candida albicans cells, the decrease of gene expression of ZO-1 and occludin is correlated with an inhibition of the NLRP3/NLRP6 inflammasome expression, suggesting that the loss of TJ integrity occurs independently of a direct $C$. albicans activity [64].

Furthermore, in response to infections, endogenous biosynthesis of nitric oxide (NO) regulates IECs functionality both directly (through free radical activity) and indirectly through cell signaling mechanisms that impact tight junction protein expression, including the PKC, MAPK (ERK, p38, JNK), Rho, and NF-kb pathways [41]. The subsequent $\mathrm{TJ}$ disruption and epithelial damages favor the intestinal translocation of microbial pathogens [41,162]. This was exemplified in IPEC-J2 exposure to fungal secreted ochratoxin, which induces ROS generation associated with an increase in intracellular $\mathrm{Ca}^{2+}$ concentrations [65]. The subsequent activation of the MLCK pathway finally leads to disruption of the TJs associated with an increase in IECs' permeability [65]. Ochratoxin has been shown to also increase Caco-2 epithelial permeability by promoting the remove of ZO-1 and claudin-1 from the TJ complex [94].

\section{Conclusions}

In conclusion, some enteric pathogens can target the junctional complex to weaken the intestinal epithelial barrier and promote their invasion. This microbial modulation of the IECs' permeability involves numerous mechanisms ranging from direct molecular interactions of microorganism with host components to the modulation of various signaling cellular pathways. Whereas many studies highlight the fate of the major TJ proteins (i.e., occludin, claudins and ZO-1) during bacterial, viral, fungal, or parasitic IEC infections, the cellular and molecular mechanisms remain to be specified, including the nature of the microbial effector, its host cellular receptor, the nature of the signaling pathways involved, as well as the direct or indirect impact of their modulation on the TJ complex organization. Finally, most of the observations reported here are based on simplified models of infection (one pathogen interacting with one type of intestinal cell) that do not consider (i) the complexity of the intestinal ecosystem and environmental conditions including the communications between pathogenic and commensal microorganisms, or (ii) the influence of the intestinal microbiota upon pathogens/epithelial cells interactions regarding the gut TJ integrity [163-165]. Pathogenic effectors and/or their cellular receptors constitute therapeutic candidates by preventing the weakening of the digestive barrier induced by pathogens. 
Funding: This research received no external funding.

Institutional Review Board Statement: Not applicable.

Informed Consent Statement: Not applicable.

Data Availability Statement: Not applicable.

Conflicts of Interest: The authors declare no conflict of interest.

\section{References}

1. Cordeiro, F.; da Silva, R.I.K.; Vargas-Stampe, T.L.Z.; Cerqueira, A.M.F.; Andrade, J.R.C. Cell Invasion and Survival of Shiga Toxin-Producing Escherichia Coli within Cultured Human Intestinal Epithelial Cells. Microbiology 2013, 159 Pt 8, $1683-1694$. [CrossRef]

2. Goyer, M.; Loiselet, A.; Bon, F.; L'Ollivier, C.; Laue, M.; Holland, G.; Bonnin, A.; Dalle, F. Intestinal Cell Tight Junctions Limit Invasion of Candida Albicans through Active Penetration and Endocytosis in the Early Stages of the Interaction of the Fungus with the Intestinal Barrier. PLoS ONE 2016, 11, e0149159. [CrossRef] [PubMed]

3. Peng, L.; Li, Z.-R.; Green, R.S.; Holzman, I.R.; Lin, J. Butyrate Enhances the Intestinal Barrier by Facilitating Tight Junction Assembly via Activation of AMP-Activated Protein Kinase in Caco-2 Cell Monolayers. J. Nutr. 2009, 139, 1619-1625. [CrossRef]

4. Miao, W.; Wu, X.; Wang, K.; Wang, W.; Wang, Y.; Li, Z.; Liu, J.; Li, L.; Peng, L. Sodium Butyrate Promotes Reassembly of Tight Junctions in Caco-2 Monolayers Involving Inhibition of MLCK/MLC2 Pathway and Phosphorylation of PKC $\beta 2$. Int. J. Mol. Sci. 2016, 17, 1696. [CrossRef]

5. Holscher, H.D. Dietary Fiber and Prebiotics and the Gastrointestinal Microbiota. Gut Microbes 2017, 8, 172-184. [CrossRef] [PubMed]

6. Yan, H.; Ajuwon, K.M. Butyrate Modifies Intestinal Barrier Function in IPEC-J2 Cells through a Selective Upregulation of Tight Junction Proteins and Activation of the Akt Signaling Pathway. PLoS ONE 2017, 12, e0179586. [CrossRef]

7. Gill, P.A.; van Zelm, M.C.; Muir, J.G.; Gibson, P.R. Review Article: Short Chain Fatty Acids as Potential Therapeutic Agents in Human Gastrointestinal and Inflammatory Disorders. Aliment. Pharmacol. Ther. 2018, 48, 15-34. [CrossRef]

8. Wan, M.L.Y.; Forsythe, S.J.; El-Nezami, H. Probiotics Interaction with Foodborne Pathogens: A Potential Alternative to Antibiotics and Future Challenges. Crit. Rev. Food Sci. Nutr. 2019, 59, 3320-3333. [CrossRef] [PubMed]

9. Guttman, J.A.; Finlay, B.B. Tight Junctions as Targets of Infectious Agents. Biochim. Biophys. Acta BBA Biomembr. 2009, 1788, 832-841. [CrossRef] [PubMed]

10. Backert, S.; Boehm, M.; Wessler, S.; Tegtmeyer, N. Transmigration Route of Campylobacter Jejuni across Polarized Intestinal Epithelial Cells: Paracellular, Transcellular or Both? Cell Commun. Signal. 2013, 11, 72. [CrossRef]

11. Yu, Q.; Yang, Q. Diversity of Tight Junctions (TJs) between Gastrointestinal Epithelial Cells and Their Function in Maintaining the Mucosal Barrier. Cell Biol. Int. 2009, 33, 78-82. [CrossRef] [PubMed]

12. Zihni, C.; Mills, C.; Matter, K.; Balda, M.S. Tight Junctions: From Simple Barriers to Multifunctional Molecular Gates. Nat. Rev. Mol. Cell Biol. 2016, 17, 564-580. [CrossRef] [PubMed]

13. Zahraoui, A. Les Jonctions Serrées. Med. Sci. 2004, 20, 580-585.

14. Matter, K.; Aijaz, S.; Tsapara, A.; Balda, M.S. Mammalian Tight Junctions in the Regulation of Epithelial Differentiation and Proliferation. Curr. Opin. Cell Biol. 2005, 17, 453-458. [CrossRef]

15. Severson, E.A.; Lee, W.Y.; Capaldo, C.T.; Nusrat, A.; Parkos, C.A. Junctional Adhesion Molecule A Interacts with Afadin and PDZ-GEF2 to Activate Rap1A, Regulate beta 1 Integrin Levels, and Enhance Cell Migration. Mol. Biol. Cell 2009, 20, 1916-1925. [CrossRef]

16. Lu, R.-Y.; Yang, W.-X.; Hu, Y.-J. The Role of Epithelial Tight Junctions Involved in Pathogen Infections. Mol. Biol. Rep. 2014, 41, 6591-6610. [CrossRef] [PubMed]

17. Campbell, H.K.; Maiers, J.L.; DeMali, K.A. Interplay between Tight Junctions \& Adherens Junctions. Exp. Cell Res. 2017, 358, 39-44. [CrossRef]

18. Matter, K.; Balda, M.S. SnapShot: Epithelial Tight Junctions. Cell 2014, 157, 2. [CrossRef]

19. Balda, M.S.; Gonzalez-Mariscal, L.; Contreras, R.G.; Macias-Silva, M.; Torres-Marquez, M.E.; Sainz, J.G.; Cereijido, M. Assembly and Sealing of Tight Junctions: Possible Participation of G-Proteins, Phospholipase C, Protein Kinase C and Calmodulin. J. Membr. Biol. 1991, 122, 193-202. [CrossRef]

20. Zihni, C.; Munro, P.M.G.; Elbediwy, A.; Keep, N.H.; Terry, S.J.; Harris, J.; Balda, M.S.; Matter, K. Dbl3 Drives Cdc42 Signaling at the Apical Margin to Regulate Junction Position and Apical Differentiation. J. Cell Biol. 2014, 204, 111-127. [CrossRef]

21. González-Mariscal, L.; Domínguez-Calderón, A.; Raya-Sandino, A.; Ortega-Olvera, J.M.; Vargas-Sierra, O.; Martínez-Revollar, G. Tight Junctions and the Regulation of Gene Expression. Semin. Cell Dev. Biol. 2014, 36, 213-223. [CrossRef]

22. Quiros, M.; Nusrat, A. RhoGTPases, Actomyosin Signaling and Regulation of the Epithelial Apical Junctional Complex. Semin. Cell Dev. Biol. 2014, 36, 194-203. [CrossRef] [PubMed]

23. Olivier, S.; Leclerc, J.; Grenier, A.; Foretz, M.; Tamburini, J.; Viollet, B. AMPK Activation Promotes Tight Junction Assembly in Intestinal Epithelial Caco-2 Cells. Int. J. Mol. Sci. 2019, 20, 5171. [CrossRef] 
24. Ma, T.Y.; Nighot, P.; Al-Sadi, R. Tight Junctions and the Intestinal Barrier. In Physiology of the Gastrointestinal Tract; Academic Press: Cambridge, MA, USA, 2018; pp. 587-639. [CrossRef]

25. Yu, D.; Turner, J.R. Stimulus-Induced Reorganization of Tight Junction Structure: The Role of Membrane Traffic. Biochim. Biophys. Acta BBA Biomembr. 2008, 1778, 709-716. [CrossRef]

26. Steed, E.; Balda, M.S.; Matter, K. Dynamics and Functions of Tight Junctions. Trends Cell Biol. 2010, 20, 142-149. [CrossRef]

27. Cargnello, M.; Roux, P.P. Activation and Function of the MAPKs and Their Substrates, the MAPK-Activated Protein Kinases. Microbiol. Mol. Biol. Rev. 2011, 75, 35. [CrossRef]

28. Samak, G.; Gangwar, R.; Crosby, L.M.; Desai, L.P.; Wilhelm, K.; Waters, C.M.; Rao, R. Cyclic Stretch Disrupts Apical Junctional Complexes in Caco-2 Cell Monolayers by a JNK-2-, c-Src-, and MLCK-Dependent Mechanism. Am. J. Physiol. Gastrointest. Liver Physiol. 2014, 306, G947-G958. [CrossRef] [PubMed]

29. Beutheu, S.; Ouelaa, W.; Guérin, C.; Belmonte, L.; Aziz, M.; Tennoune, N.; Bôle-Feysot, C.; Galas, L.; Déchelotte, P.; Coëffier, M. Glutamine Supplementation, but Not Combined Glutamine and Arginine Supplementation, Improves Gut Barrier Function during Chemotherapy-Induced Intestinal Mucositis in Rats. Clin. Nutr. 2014, 33, 694-701. [CrossRef]

30. Wang, B.; Wu, Z.; Ji, Y.; Sun, K.; Dai, Z.; Wu, G. L-Glutamine Enhances Tight Junction Integrity by Activating CaMK Kinase 2-AMP-Activated Protein Kinase Signaling in Intestinal Porcine Epithelial Cells. J. Nutr. 2016, 146, 501-508. [CrossRef] [PubMed]

31. Aggarwal, S.; Suzuki, T.; Taylor, W.L.; Bhargava, A.; Rao, R.K. Contrasting Effects of ERK on Tight Junction Integrity in Differentiated and Under-Differentiated Caco-2 Cell Monolayers. Biochem. J. 2011, 433, 51-63. [CrossRef]

32. Fasano, A.; Not, T.; Wang, W.; Uzzau, S.; Berti, I.; Tommasini, A.; Goldblum, S.E. Zonulin, a Newly Discovered Modulator of Intestinal Permeability, and Its Expression in Coeliac Disease. Lancet 2000, 355, 1518-1519. [CrossRef]

33. Asmar, R.E.; Panigrahi, P.; Bamford, P.; Berti, I.; Not, T.; Coppa, G.V.; Catassi, C.; Fasano, A. Host-Dependent Zonulin Secretion Causes the Impairment of the Small Intestine Barrier Function after Bacterial Exposure. Gastroenterology 2002, 123, $1607-1615$. [CrossRef]

34. Fasano, A. Intestinal Permeability and Its Regulation by Zonulin: Diagnostic and Therapeutic Implications. Clin. Gastroenterol. Hepatol. 2012, 10, 1096-1100. [CrossRef]

35. Fasano, A. Zonulin, Regulation of Tight Junctions, and Autoimmune Diseases: Zonulin, Regulation of Tight Junctions. Ann. N. Y. Acad. Sci. 2012, 1258, 25-33. [CrossRef]

36. Turner, J.R. Molecular Basis of Epithelial Barrier Regulation. Am. J. Pathol. 2006, 169, 1901-1909. [CrossRef]

37. Nusrat, A.; von Eichel-Streiber, C.; Turner, J.R.; Verkade, P.; Madara, J.L.; Parkos, C.A. Clostridium Difficile Toxins Disrupt Epithelial Barrier Function by Altering Membrane Microdomain Localization of Tight Junction Proteins. Infect. Immun. 2001, 69, 1329-1336. [CrossRef] [PubMed]

38. Walsh, S.V.; Hopkins, A.M.; Chen, J.; Narumiya, S.; Parkos, C.A.; Nusrat, A. Rho Kinase Regulates Tight Junction Function and Is Necessary for Tight Junction Assembly in Polarized Intestinal Epithelia. Gastroenterology 2001, 121, 566-579. [CrossRef]

39. Rao, R.; Samak, G. Role of Glutamine in Protection of Intestinal Epithelial Tight Junctions. J. Epithel. Biol. Pharmacol. 2012, 5, 47-54. [CrossRef]

40. Citi, S.; Guerrera, D.; Spadaro, D.; Shah, J. Epithelial Junctions and Rho Family GTPases: The Zonular Signalosome. Small GTPases 2014, 5, e973760. [CrossRef]

41. Mu, K.; Yu, S.; Kitts, D.D. The Role of Nitric Oxide in Regulating Intestinal Redox Status and Intestinal Epithelial Cell Functionality. Int. J. Mol. Sci. 2019, 20, 1755. [CrossRef]

42. Langen, U.H.; Ayloo, S.; Gu, C. Development and Cell Biology of the Blood-Brain Barrier. Annu. Rev. Cell Dev. Biol. 2019, 35, 591-613. [CrossRef]

43. Cong, X.; Kong, W. Endothelial Tight Junctions and Their Regulatory Signaling Pathways in Vascular Homeostasis and Disease. Cell. Signal. 2020, 66, 109485. [CrossRef]

44. Cerutti, C.; Ridley, A.J. Endothelial Cell-Cell Adhesion and Signaling. Exp. Cell Res. 2017, 358, 31-38. [CrossRef]

45. Cardoso-Silva, D.; Delbue, D.; Itzlinger, A.; Moerkens, R.; Withoff, S.; Branchi, F.; Schumann, M. Intestinal Barrier Function in Gluten-Related Disorders. Nutrients 2019, 11, 2325. [CrossRef]

46. Torres-Flores, J.; Arias, C. Tight Junctions Go Viral! Viruses 2015, 7, 5145-5154. [CrossRef] [PubMed]

47. Di Genova, B.M.; Tonelli, R.R. Infection Strategies of Intestinal Parasite Pathogens and Host Cell Responses. Front. Microbiol. 2016, 7. [CrossRef]

48. Awad, W.; Hess, C.; Hess, M. Enteric Pathogens and Their Toxin-Induced Disruption of the Intestinal Barrier through Alteration of Tight Junctions in Chickens. Toxins 2017, 9, 60. [CrossRef]

49. Dickman, K.G.; Hempson, S.J.; Anderson, J.; Lippe, S.; Zhao, L.; Burakoff, R.; Shaw, R.D. Rotavirus Alters Paracellular Permeability and Energy Metabolism in Caco-2 Cells. Am. J. Physiol. Gastrointest. Liver Physiol. 2000, 279, 757-766. [CrossRef] [PubMed]

50. Obert, G.; Peiffer, I.; Servin, A.L. Rotavirus-Induced Structural and Functional Alterations in Tight Junctions of Polarized Intestinal Caco-2 Cell Monolayers. J. Virol. 2000, 74, 4645-4651. [CrossRef]

51. Moser, L.A.; Carter, M.; Schultz-Cherry, S. Astrovirus Increases Epithelial Barrier Permeability Independently of Viral Replication. J. Virol. 2007, 81, 11937-11945. [CrossRef] [PubMed]

52. Wu, Z.; Nybom, P.; Magnusson, K.-E. Distinct Effects of Vibrio Cholerae Haemagglutinin/Protease on the Structure and Localization of the Tight Junction-Associated Proteins Occludin and ZO-1. Cell. Microbiol. 2000, 2, 11-17. [CrossRef] [PubMed] 
53. Mel, S.F.; Fullner, K.J.; Wimer-Mackin, S.; Lencer, W.I.; Mekalanos, J.J. Association of Protease Activity in Vibrio Cholerae Vaccine Strains with Decreases in Transcellular Epithelial Resistance of Polarized T84 Intestinal Epithelial Cells. Infect. Immun. 2000, 68, 6. [CrossRef]

54. Bücker, R.; Krug, S.M.; Rosenthal, R.; Günzel, D.; Fromm, A.; Zeitz, M.; Chakraborty, T.; Fromm, M.; Epple, H.-J.; Schulzke, J.-D. Aerolysin From Aeromonas Hydrophila Perturbs Tight Junction Integrity and Cell Lesion Repair in Intestinal Epithelial HT-29/B6 Cells. J. Infect. Dis. 2011, 204, 1283-1292. [CrossRef]

55. Elmi, A.; Nasher, F.; Jagatia, H.; Gundogdu, O.; Bajaj-Elliott, M.; Wren, B.; Dorrell, N. Campylobacter Jejuni Outer Membrane Vesicle-Associated Proteolytic Activity Promotes Bacterial Invasion by Mediating Cleavage of Intestinal Epithelial Cell E-Cadherin and Occludin: Campylobacter Jejuni OMV-Associated Proteolytic Activity. Cell. Microbiol. 2016, 18, 561-572. [CrossRef]

56. Harrer, A.; Bücker, R.; Zarzecka, U.; Tegtmeyer, N.; Sticht, H.; Schulzke, J.D.; Backert, S. Campylobacter Jejuni Enters Gut Epithelial Cells and Impairs Intestinal Barrier Function through Cleavage of Occludin by Serine Protease HtrA. Gut Pathog. 2019, 11, 16. [CrossRef]

57. Weight, C.M.; Jones, E.J.; Horn, N.; Wellner, N.; Carding, S.R. Elucidating Pathways of Toxoplasma Gondii Invasion in the Gastrointestinal Tract: Involvement of the Tight Junction Protein Occludin. Microbes Infect. 2015, 17, 698-709. [CrossRef] [PubMed]

58. Beau, I.; Cotte-Laffitte, J.; Amsellem, R.; Servin, A.L. A Protein Kinase A-Dependent Mechanism by Which Rotavirus Affects the Distribution and MRNA Level of the Functional Tight Junction-Associated Protein, Occludin, in Human Differentiated Intestinal Caco-2 Cells. J. Virol. 2007, 81, 8579-8586. [CrossRef]

59. Alvarez, C.-S.; Giménez, R.; Cañas, M.-A.; Vera, R.; Díaz-Garrido, N.; Badia, J.; Baldomà, L. Extracellular Vesicles and Soluble Factors Secreted by Escherichia Coli Nissle 1917 and ECOR63 Protect against Enteropathogenic E. Coli-Induced Intestinal Epithelial Barrier Dysfunction. BMC Microbiol. 2019, 19, 166. [CrossRef]

60. Ngendahayo Mukiza, C.; Dubreuil, J.D. Escherichia Coli Heat-Stable Toxin b Impairs Intestinal Epithelial Barrier Function by Altering Tight Junction Proteins. Infect. Immun. 2013, 81, 2819-2827. [CrossRef]

61. Coyne, C.B.; Shen, L.; Turner, J.R.; Bergelson, J.M. Coxsackievirus Entry across Epithelial Tight Junctions Requires Occludin and the Small GTPases Rab34 and Rab5. Cell Host Microbe 2007, 2, 181-192. [CrossRef] [PubMed]

62. Coyne, C.B.; Bergelson, J.M. Virus-Induced Abl and Fyn Kinase Signals Permit Coxsackievirus Entry through Epithelial Tight Junctions. Cell 2006, 124, 119-131. [CrossRef] [PubMed]

63. Drolia, R.; Tenguria, S.; Durkes, A.C.; Turner, J.R.; Bhunia, A.K. Listeria Adhesion Protein Induces Intestinal Epithelial Barrier Dysfunction for Bacterial Translocation. Cell Host Microbe 2018, 23, 470-484.e7. [CrossRef]

64. Mao, X.; Qiu, X.; Jiao, C.; Lu, M.; Zhao, X.; Li, X.; Li, J.; Ma, J.; Zhang, H. And Dampens Human Intestinal Barrier Activity in Caco-2 Cell Monolayer Model. Cytokine 2020, 126, 7. [CrossRef]

65. Wang, H.; Zhai, N.; Chen, Y.; Fu, C.; Huang, K. OTA Induces Intestinal Epithelial Barrier Dysfunction and Tight Junction Disruption in IPEC-J2 Cells through ROS/Ca2+-Mediated MLCK Activation. Environ. Pollut. 2018, 242, 106-112. [CrossRef]

66. Boyle, E.C.; Brown, N.F.; Finlay, B.B. Salmonella Enterica Serovar Typhimurium Effectors SopB, SopE, SopE2 and SipA Disrupt Tight Junction Structure and Function. Cell. Microbiol. 2006, 8, 1946-1957. [CrossRef]

67. Sakaguchi, T.; Köhler, H.; Gu, X.; McCormick, B.A.; Reinecker, H.-C. Shigella Flexneri Regulates Tight Junction-Associated Proteins in Human Intestinal Epithelial Cells. Cell. Microbiol. 2002, 4, 367-381. [CrossRef]

68. Bhat, M.I.; Sowmya, K.; Kapila, S.; Kapila, R. Escherichia Coli K12: An Evolving Opportunistic Commensal Gut Microbe Distorts Barrier Integrity in Human Intestinal Cells. Microb. Pathog. 2019, 133, 103545. [CrossRef]

69. Bhat, M.I.; Kapila, S.; Kapila, R. Lactobacillus Fermentum (MTCC-5898) Supplementation Renders Prophylactic Action against Escherichia Coli Impaired Intestinal Barrier Function through Tight Junction Modulation. LWT 2020, 123, 109118. [CrossRef]

70. Troeger, H.; Loddenkemper, C.; Schneider, T.; Schreier, E.; Epple, H.-J.; Zeitz, M.; Fromm, M.; Schulzke, J.D. Structural and Functional Changes of the Duodenum in Human Norovirus Infection. Gut 2009, 58, 1070-1077. [CrossRef] [PubMed]

71. Nazli, A.; Chan, O.; Dobson-Belaire, W.N.; Ouellet, M.; Tremblay, M.J.; Gray-Owen, S.D.; Arsenault, A.L.; Kaushic, C. Exposure to HIV-1 Directly Impairs Mucosal Epithelial Barrier Integrity Allowing Microbial Translocation. PLoS Pathog. 2010, 6, e1000852. [CrossRef] [PubMed]

72. Nava, P.; Vidal, J.E. The CpAL System Regulates Changes of the Trans-Epithelial Resistance of Human Enterocytes during Clostridium Perfringens Type C Infection. Anaerobe 2016, 39, 143-149. [CrossRef]

73. Strauman, M.C.; Harper, J.M.; Harrington, S.M.; Boll, E.J.; Nataro, J.P. Enteroaggregative Escherichia Coli Disrupts Epithelial Cell Tight Junctions. Infect. Immun. 2010, 78, 4958-4964. [CrossRef]

74. Philpott, D.J.; McKay, D.M.; Mak, W.; Perdue, M.H.; Sherman, P.M. Signal Transduction Pathways Involved in Enterohemorrhagic Escherichia Coli-Induced Alterations in T84 Epithelial Permeability. Infect. Immun. 1998, 66, 1680-1687. [CrossRef] [PubMed]

75. Roxas, J.L.; Koutsouris, A.; Bellmeyer, A.; Tesfay, S.; Royan, S.; Falzari, K.; Harris, A.; Cheng, H.; Rhee, K.J.; Hecht, G. Enterohemorrhagic E. Coli Alters Murine Intestinal Epithelial Tight Junction Protein Expression and Barrier Function in a Shiga Toxin Independent Manner. Lab. Investig. 2010, 90, 1152-1168. [CrossRef]

76. Fedwick, J.P.; Lapointe, T.K.; Meddings, J.B.; Sherman, P.M.; Buret, A.G. Helicobacter Pylori Activates Myosin Light-Chain Kinase to Disrupt Claudin-4 and Claudin-5 and Increase Epithelial Permeability. Infect. Immun. 2005, 73, 7844-7852. [CrossRef] 
77. Köhler, H.; Sakaguchi, T.; Hurley, B.P.; Kase, B.J.; Reinecker, H.-C.; McCormick, B.A. Salmonella Enterica Serovar Typhimurium Regulates Intercellular Junction Proteins and Facilitates Transepithelial Neutrophil and Bacterial Passage. Am. J. Physiol. Gastrointest. Liver Physiol. 2007, 293, G178-G187. [CrossRef]

78. Zhang, L.; Gui, S.; Liang, Z.; Liu, A.; Chen, Z.; Tang, Y.; Xiao, M.; Chu, F.; Liu, W.; Jin, X.; et al. Musca Domestica Cecropin (Mdc) Alleviates Salmonella Typhimurium-Induced Colonic Mucosal Barrier Impairment: Associating with Inflammatory and Oxidative Stress Response, Tight Junction as Well as Intestinal Flora. Front. Microbiol. 2019, 10, 522. [CrossRef] [PubMed]

79. Kwak, Y.-K.; Vikström, E.; Magnusson, K.-E.; Vécsey-Semjén, B.; Colque-Navarro, P.; Möllby, R. The Staphylococcus Aureus Alpha-Toxin Perturbs the Barrier Function in Caco-2 Epithelial Cell Monolayers by Altering Junctional Integrity. Infect. Immun. 2012, 80, 1670-1680. [CrossRef]

80. Hering, N.A.; Fromm, A.; Kikhney, J.; Lee, I.-F.M.; Moter, A.; Schulzke, J.D.; Bücker, R. Yersinia Enterocolitica Affects Intestinal Barrier Function in the Colon. J. Infect. Dis. 2016, 213, 1157-1162. [CrossRef]

81. Carballeda-Sangiao, N.; Sánchez-Alonso, I.; Navas, A.; Arcos, S.C.; de Palencia, P.F.; Careche, M.; González-Muñoz, M. Anisakis Simplex Products Impair Intestinal Epithelial Barrier Function and Occludin and Zonula Occludens-1 Localisation in Differentiated Caco-2 Cells. PLoS Negl. Trop. Dis. 2020, 14, e0008462. [CrossRef] [PubMed]

82. McLaughlin, J.; Lambert, D.; Padfield, P.J.; Burt, J.P.H.; O'Neill, C.A. The Mycotoxin Patulin, Modulates Tight Junctions in Caco-2 Cells. Toxicol. In Vitro 2009, 23, 83-89. [CrossRef]

83. Wu, Z.; Mirza, H.; Tan, K.S.W. Intra-Subtype Variation in Enteroadhesion Accounts for Differences in Epithelial Barrier Disruption and Is Associated with Metronidazole Resistance in Blastocystis Subtype-7. PLoS Negl. Trop. Dis. 2014, 8, e2885. [CrossRef]

84. Böhringer, M.; Pohlers, S.; Schulze, S.; Albrecht-Eckardt, D.; Piegsa, J.; Weber, M.; Martin, R.; Hünniger, K.; Linde, J.; Guthke, R.; et al. Candida Albicans Infection Leads to Barrier Breakdown and a MAPK/NF-KB Mediated Stress Response in the Intestinal Epithelial Cell Line C2BBe1: Epithelial Barrier Breakdown by C. Albicans. Cell. Microbiol. 2016, 18, 889-904. [CrossRef]

85. Kumar, A.; Chatterjee, I.; Anbazhagan, A.N.; Jayawardena, D.; Priyamvada, S.; Alrefai, W.A.; Sun, J.; Borthakur, A.; Dudeja, P.K. Cryptosporidium Parvum Disrupts Intestinal Epithelial Barrier Function via Altering Expression of Key Tight Junction and Adherens Junction Proteins. Cell. Microbiol. 2018, 20, e12830. [CrossRef]

86. Humen, M.A.; Pérez, P.F.; Liévin-Le Moal, V. Lipid Raft-Dependent Adhesion of Giardia Intestinalis Trophozoites to a Cultured Human Enterocyte-like Caco-2/TC7 Cell Monolayer Leads to Cytoskeleton-Dependent Functional Injuries: Giardia IntestinalisInduced Cytoskeleton-Dependent Intestinal Functional Injuries. Cell. Microbiol. 2011, 13, 1683-1702. [CrossRef]

87. Morampudi, V.; Graef, F.A.; Stahl, M.; Dalwadi, U.; Conlin, V.S.; Huang, T.; Vallance, B.A.; Yu, H.B.; Jacobson, K. Tricellular Tight Junction Protein Tricellulin Is Targeted by the Enteropathogenic Escherichia Coli Effector EspG1, Leading to Epithelial Barrier Disruption. Infect. Immun. 2017, 85. [CrossRef] [PubMed]

88. Yuhan, R.; Koutsouris, A.; Savkovic, S.D.; Hecht, G. Enteropathogenic Escherichia Coli-Induced Myosin Light Chain Phosphorylation Alters Intestinal Epithelial Permeability. Gastroenterology 1997, 113, 1873-1882. [CrossRef]

89. Dean, P.; Kenny, B. The Effector Repertoire of Enteropathogenic E. Coli: Ganging up on the Host Cell. Curr. Opin. Microbiol. 2009, 12, 101-109. [CrossRef] [PubMed]

90. Eichner, M.; Augustin, C.; Fromm, A.; Piontek, A.; Walther, W.; Bücker, R.; Fromm, M.; Krause, G.; Schulzke, J.-D.; Günzel, D.; et al. In Colon Epithelia, Clostridium Perfringens Enterotoxin Causes Focal Leaks by Targeting Claudins Which Are Apically Accessible Due to Tight Junction Derangement. J. Infect. Dis. 2018, 217, 147-157. [CrossRef]

91. Sarkar, P.; Saha, T.; Sheikh, I.A.; Chakraborty, S.; Aoun, J.; Chakrabarti, M.K.; Rajendran, V.M.; Ameen, N.A.; Dutta, S.; Hoque, K.M. Zinc Ameliorates Intestinal Barrier Dysfunctions in Shigellosis by Reinstating Claudin-2 and -4 on the Membranes. Am. J. Physiol. Gastrointest. Liver Physiol. 2019, 316, 229-246. [CrossRef] [PubMed]

92. Hering, N.A.; Richter, J.F.; Krug, S.M.; Günzel, D.; Fromm, A.; Bohn, E.; Rosenthal, R.; Bücker, R.; Fromm, M.; Troeger, H.; et al. Yersinia Enterolitica Induces Epithelial Barrier Dysfunction through Regional Tight Junction Changes in Colonic HT-29/B6 Cell Monolayers. Lab. Investig. 2011, 91, 301-324. [CrossRef] [PubMed]

93. Katsuyama, A.; Konno, T.; Shimoyama, S.; Kikuchi, H. The Mycotoxin Patulin Decreases Expression of Density-Enhanced Phosphatase-1 by Down-Regulating PPAR $\gamma$ in Human Colon Cancer Cells. Tohoku J. Exp. Med. 2014, 233, 265-274. [CrossRef]

94. Peng, M.; Liu, J.; Liang, Z. Probiotic Bacillus Subtilis CW14 Reduces Disruption of the Epithelial Barrier and Toxicity of Ochratoxin A to Caco-2 Cells. Food Chem. Toxicol. 2019, 126, 25-33. [CrossRef] [PubMed]

95. Epple, H.-J.; Schneider, T.; Troeger, H.; Kunkel, D.; Allers, K.; Moos, V.; Amasheh, M.; Loddenkemper, C.; Fromm, M.; Zeitz, M.; et al. Impairment of the Intestinal Barrier Is Evident in Untreated but Absent in Suppressively Treated HIV- Infected Patients. Gut 2009, 58, 220-227. [CrossRef] [PubMed]

96. Lamb-Rosteski, J.M.; Kalischuk, L.D.; Inglis, G.D.; Buret, A.G. Epidermal Growth Factor Inhibits Campylobacter Jejuni-Induced Claudin-4 Disruption, Loss of Epithelial Barrier Function, and Escherichia Coli Translocation. Infect. Immun. 2008, 76, 3390-3398. [CrossRef]

97. Simonovic, I.; Rosenberg, J.; Koutsouris, A.; Hecht, G. Enteropathogenic Escherichia Coli Dephosphorylates and Dissociates Occludin from Intestinal Epithelial Tight Junctions. Cell. Microbiol. 2000, 2, 305-315. [CrossRef]

98. Muza-Moons, M.M.; Schneeberger, E.E.; Hecht, G.A. Enteropathogenic Escherichia Coli Infection Leads to Appearance of Aberrant Tight Junctions Strands in the Lateral Membrane of Intestinal Epithelial Cells: EPEC Induces Tight Junction Protein Redistribution. Cell. Microbiol. 2004, 6, 783-793. [CrossRef] [PubMed] 
99. Dean, P.; Kenny, B. Intestinal Barrier Dysfunction by Enteropathogenic Escherichia Coli Is Mediated by Two Effector Molecules and a Bacterial Surface Protein: Intestinal Barrier Disrupting Proteins of EPEC. Mol. Microbiol. 2004, 54, 665-675. [CrossRef] [PubMed]

100. Zhang, Q.; Li, Q.; Wang, C.; Liu, X.; Li, N.; Li, J. Enteropathogenic Escherichia Coli Changes Distribution of Occludin and ZO-1 in Tight Junction Membrane Microdomains in Vivo. Microb. Pathog. 2010, 48, 28-34. [CrossRef] [PubMed]

101. Lapointe, T.K.; O'Connor, P.M.; Jones, N.L.; Menard, D.; Buret, A.G. Interleukin-1 Receptor Phosphorylation Activates Rho Kinase to Disrupt Human Gastric Tight Junctional Claudin-4 during Helicobacter Pylori Infection. Cell. Microbiol. 2010, 12, 692-703. [CrossRef]

102. Fiorentino, M.; Ding, H.; Blanchard, T.G.; Czinn, S.J.; Sztein, M.B.; Fasano, A. Helicobacter Pylori-Induced Disruption of Monolayer Permeability and Proinflammatory Cytokine Secretion in Polarized Human Gastric Epithelial Cells. Infect. Immun. 2013, 81, 876-883. [CrossRef]

103. Popović, N.; Djokić, J.; Brdarić, E.; Dinić, M.; Terzić-Vidojević, A.; Golić, N.; Veljović, K. The Influence of Heat-Killed Enterococcus Faecium BGPAS1-3 on the Tight Junction Protein Expression and Immune Function in Differentiated Caco-2 Cells Infected with Listeria Monocytogenes ATCC 19111. Front. Microbiol. 2019, 10. [CrossRef]

104. Lejeune, M.; Moreau, F.; Chadee, K. Prostaglandin E2 Produced by Entamoeba Histolytica Signals via EP4 Receptor and Alters Claudin-4 to Increase Ion Permeability of Tight Junctions. Am. J. Pathol. 2011, 17, 807-818. [CrossRef]

105. Maia-Brigagão, C.; Morgado-Díaz, J.A.; De Souza, W. Giardia Disrupts the Arrangement of Tight, Adherens and Desmosomal Junction Proteins of Intestinal Cells. Parasitol. Int. 2012, 61, 280-287. [CrossRef]

106. Barton, E.S.; Forrest, J.C.; Connolly, J.L.; Chappell, J.D.; Liu, Y.; Schnell, F.J.; Nusrat, A.; Parkos, C.A.; Dermody, T.S. Junction Adhesion Molecule Is a Receptor for Reovirus. Cell 2001, 104, 441-451. [CrossRef]

107. Deshpande, N.P.; Wilkins, M.R.; Castaño-Rodríguez, N.; Bainbridge, E.; Sodhi, N.; Riordan, S.M.; Mitchell, H.M.; Kaakoush, N.O. Campylobacter Concisus Pathotypes Induce Distinct Global Responses in Intestinal Epithelial Cells. Sci. Rep. 2016, 6. [CrossRef] [PubMed]

108. Cohen, C.J.; Shieh, J.T.; Pickles, R.J.; Okegawa, T.; Hsieh, J.-T.; Bergelson, J.M. The Coxsackievirus and Adenovirus Receptor Is a Transmembrane Component of the Tight Junction. Proc. Natl. Acad. Sci. USA 2001, 98, 15191-15196. [CrossRef] [PubMed]

109. Krueger, S.; Hundertmark, T.; Kuester, D.; Kalinski, T.; Peitz, U.; Roessner, A. Helicobacter Pylori Alters the Distribution of ZO-1 and P120ctn in Primary Human Gastric Epithelial Cells. Pathol. Res. Pract. 2007, 203, 433-444. [CrossRef] [PubMed]

110. Kawauchiya, T.; Takumi, R.; Kudo, Y.; Takamori, A.; Sasagawa, T.; Takahashi, K.; Kikuchi, H. Correlation between the Destruction of Tight Junction by Patulin Treatment and Increase of Phosphorylation of ZO-1 in Caco-2 Human Colon Cancer Cells. Toxicol. Lett. 2011, 205, 196-202. [CrossRef] [PubMed]

111. Buret, A.G.; Chin, A.C.; Scott, K.G.E. Infection of Human and Bovine Epithelial Cells with Cryptosporidium Andersoni Induces Apoptosis and Disrupts Tight Junctional ZO-1: Effects of Epidermal Growth Factor. Int. J. Parasitol. 2003, 33, 1363-1371. [CrossRef]

112. Leroy, A.; Lauwaet, T.; De Bruyne, G.; Cornelissen, M.; Mareel, M. Entamoeba Histolytica Disturbs the Tight Junction Complex in Human Enteric T84 Cell Layers. FASEB J. 2000, 14, 1139-1146. [CrossRef]

113. Koh, W.H.; Geurden, T.; Paget, T.; O'Handley, R.; Steuart, R.F.; Thompson, R.C.A.; Buret, A.G. Giardia Duodenalis AssemblageSpecific Induction of Apoptosis and Tight Junction Disruption in Human Intestinal Epithelial Cells: Effects of Mixed Infections. J. Parasitol. 2013, 99, 353-358. [CrossRef]

114. Beatty, J.K.; Akierman, S.V.; Motta, J.-P.; Muise, S.; Workentine, M.L.; Harrison, J.J.; Bhargava, A.; Beck, P.L.; Rioux, K.P.; McKnight, G.W.; et al. Giardia Duodenalis Induces Pathogenic Dysbiosis of Human Intestinal Microbiota Biofilms. Int. J. Parasitol. 2017, 47, 311-326. [CrossRef]

115. Scott, K.G.-E.; Meddings, J.B.; Kirk, D.R.; Lees-Miller, S.P.; Buret, A.G. Intestinal Infection with Giardia Spp. Reduces Epithelial Barrier Function in a Myosin Light Chain Kinase-Dependent Fashion. Gastroenterology 2002, 123, 1179-1190. [CrossRef]

116. Bertelsen, L.S.; Paesold, G.; Marcus, S.L.; Finlay, B.B.; Eckmann, L.; Barrett, K.E. Modulation of Chloride Secretory Responses and Barrier Function of Intestinal Epithelial Cells by the Salmonella Effector Protein SigD. Am. J. Physiol. Cell Physiol. 2004, 287, 939-948. [CrossRef]

117. LaRock, D.L.; Chaudhary, A.; Miller, S.I. Salmonellae Interactions with Host Processes. Nat. Rev. Microbiol. 2015, 13, 191-205. [CrossRef]

118. Berkes, J.; Viswanathan, V.K.; Savkovic, S.D.; Hecht, G. Intestinal Epithelial Responses to Enteric Pathogens: Effects on the Tight Junction Barrier, Ion Transport, and Inflammation. Gut 2003, 52, 439-451. [CrossRef]

119. Allam, O.; Samarani, S.; Mehraj, V.; Jenabian, M.-A.; Tremblay, C.; Routy, J.-P.; Amre, D.; Ahmad, A. HIV Induces Production of IL-18 from Intestinal Epithelial Cells That Increases Intestinal Permeability and Microbial Translocation. PLoS ONE 2018, 13, e0194185. [CrossRef] [PubMed]

120. Koshy, S.S.; Montrose, M.H.; Sears, C.L. Human Intestinal Epithelial Cells Swell and Demonstrate Actin Rearrangement in Response to the Metalloprotease Toxin of Bacteroides Fragilis. Infect. Immun. 1996, 64, 5022-5028. [CrossRef] [PubMed]

121. Chambers, F.G.; Koshy, S.S.; Saidi, R.F.; Clark, D.P.; Moore, R.D.; Sears, C.L. Bacteroides Fragilis Toxin Exhibits Polar Activity on Monolayers of Human Intestinal Epithelial Cells (T84 Cells) in Vitro. Infect. Immun. 1997, 65, 3561-3570. [CrossRef] [PubMed]

122. Wu, S.; Lim, K.-C.; Huang, J.; Saidi, R.F.; Sears, C.L. Bacteroides Fragilis Enterotoxin Cleaves the Zonula Adherens Protein, E-Cadherin. Proc. Natl. Acad. Sci. USA 1998, 95, 14979-14984. [CrossRef] 
123. Seike, S.; Takehara, M.; Takagishi, T.; Miyamoto, K.; Kobayashi, K.; Nagahama, M. Delta-Toxin from Clostridium Perfringens Perturbs Intestinal Epithelial Barrier Function in Caco-2 Cell Monolayers. Biochim. Biophys. Acta BBA Biomembr. 2018, 1860, 428-433. [CrossRef]

124. Maldonado-Contreras, A.; Birtley, J.R.; Boll, E.; Zhao, Y.; Mumy, K.L.; Toscano, J.; Ayehunie, S.; Reinecker, H.-C.; Stern, L.J.; McCormick, B.A. Shigella Depends on SepA to Destabilize the Intestinal Epithelial Integrity via Cofilin Activation. Gut Microbes 2017, 8, 544-560. [CrossRef] [PubMed]

125. Schmidt, E.; Kelly, S.M.; van der Walle, C.F. Tight Junction Modulation and Biochemical Characterization of the Zonula Occludens Toxin C-and N-Termini. FEBS Lett. 2007, 581, 2974-2980. [CrossRef]

126. Hering, N.A.; Andres, S.; Fromm, A.; van Tol, E.A.; Amasheh, M.; Mankertz, J.; Fromm, M.; Schulzke, J.D. Transforming Growth Factor- $\beta$, a Whey Protein Component, Strengthens the Intestinal Barrier by Upregulating Claudin-4 in HT-29/B6 Cells. J. Nutr. 2011, 141, 783-789. [CrossRef] [PubMed]

127. Assunção, R.; Alvito, P.; Kleiveland, C.R.; Lea, T.E. Characterization of in Vitro Effects of Patulin on Intestinal Epithelial and Immune Cells. Toxicol. Lett. 2016, 250-251, 47-56. [CrossRef] [PubMed]

128. Mirza, H.; Wu, Z.; Teo, J.D.W.; Tan, K.S.W. Statin Pleiotropy Prevents Rho Kinase-Mediated Intestinal Epithelial Barrier Compromise Induced by Blastocystis Cysteine Proteases: Blastocystis Disrupts Intestinal Epithelial Barrier. Cell. Microbiol. 2012, 14, 1474-1484. [CrossRef] [PubMed]

129. Nourrisson, C.; Wawrzyniak, I.; Cian, A.; Livrelli, V.; Viscogliosi, E.; Delbac, F.; Poirier, P. On Blastocystis Secreted Cysteine Proteases: A Legumain-Activated Cathepsin B Increases Paracellular Permeability of Intestinal Caco-2 Cell Monolayers. Parasitology 2016, 143, 1713-1722. [CrossRef]

130. Cuellar, P.; Hernández-Nava, E.; García-Rivera, G.; Chávez-Munguía, B.; Schnoor, M.; Betanzos, A.; Orozco, E. Entamoeba Histolytica EhCP112 Dislocates and Degrades Claudin-1 and Claudin-2 at Tight Junctions of the Intestinal Epithelium. Front. Cell. Infect. Microbiol. 2017, 7. [CrossRef] [PubMed]

131. Kowalik, S.; Clauss, W.; Zahner, H. Toxoplasma Gondii: Changes of Transepithelial Ion Transport in Infected HT29/B6 Cell Monolayers. Parasitol. Res. 2004, 92, 152-158. [CrossRef]

132. Barbieri, J.T.; Riese, M.J.; Aktories, K. Bacterial Toxins That Modify the Actin Cytoskeleton. Annu. Rev. Cell Dev. Biol. 2002, 18, 315-344. [CrossRef]

133. Radhakrishnan, G.K.; Splitter, G.A. Modulation of Host Microtubule Dynamics by Pathogenic Bacteria. Biomol. Concepts 2012, 3, 571-580. [CrossRef]

134. Roxas, J.L.; Viswanathan, V.K. Modulation of Intestinal Paracellular Transport by Bacterial Pathogens. In Comprehensive Physiology; Terjung, R., Ed.; John Wiley \& Sons, Inc.: Hoboken, NJ, USA, 2018; pp. 823-842. [CrossRef]

135. Ramalingam, S.; Bahuguna, A.; Kim, M. The Effects of Mycotoxin Patulin on Cells and Cellular Components. Trends Food Sci. Technol. 2019, 83, 99-113. [CrossRef]

136. Chen, M.L.; Pothoulakis, C.; LaMont, J.T. Protein Kinase C Signaling Regulates ZO-1 Translocation and Increased Paracellular Flux of T84 Colonocytes Exposed to Clostridium Difficile Toxin A. J. Biol. Chem. 2002, 277, 4247-4254. [CrossRef] [PubMed]

137. Fasano, A.; Fiorentini, C.; Donelli, G.; Uzzau, S.; Ding, X.; Guandalini, S. Zonula Occludens Toxin Modulates Tight Junctions through Protein Kinase C- Dependent Actin Reorganization, In Vitro. J. Clin. Investig. 1995, 96, 710-720. [CrossRef] [PubMed]

138. Fasano, A.; Uzzau, S.; Fiore, C.; Margaretten, K. The Enterotoxic Effect of Zonula Occludens Toxin on Rabbit Small Intestine Involves the Paracellular Pathway. Gastroenterology 1997, 112, 839-846. [CrossRef] [PubMed]

139. Wang, W.; Uzzau, S.; Goldblum, S.E.; Fasano, A. Human Zonulin, a Potential Modulator of Intestinal Tight Junctions. J. Cell Sci. 2000, 113, 4435-4440.

140. Robert, H.; Payros, D.; Pinton, P.; Théodorou, V.; Mercier-Bonin, M.; Oswald, I.P. Impact of Mycotoxins on the Intestine: Are Mucus and Microbiota New Targets? J. Toxicol. Environ. Health Part B 2017, 20, 249-275. [CrossRef]

141. Sears, C.L. The Toxins of Bacteroides Fragilis. Toxicon 2001, 39, 1737-1746. [CrossRef]

142. Popoff, M. Multifaceted Interactions of Bacterial Toxins with the Gastrointestinal Mucosa. Future Microbiol. 2011,6 , $763-797$. [CrossRef]

143. Boehm, M.; Simson, D.; Escher, U.; Schmidt, A.-M.; Bereswill, S.; Tegtmeyer, N.; Backert, S.; Heimesaat, M.M. Function of Serine Protease HtrA in the Lifecycle of the Foodborne Pathogen Campylobacter Jejuni. Eur. J. Microbiol. Immunol. 2018, 8, 70-77. [CrossRef]

144. Forte, L.R.; Thorne, P.K.; Eber, S.L.; Krause, W.J.; Freeman, R.H.; Francis, S.H.; Corbin, J.D. Stimulation of Intestinal Cl- Transport by Heat-Stable Enterotoxin: Activation of CAMP-Dependent Protein Kinase by CGMP. Am. J. Physiol. Cell Physiol. 1992, 263, 607-615. [CrossRef] [PubMed]

145. Nakashima, R.; Kamata, Y.; Nishikawa, Y. Effects of Escherichia Coli Heat-Stable Enterotoxin and Guanylin on the Barrier Integrity of Intestinal Epithelial T84 Cells. Vet. Immunol. Immunopathol. 2013, 152, 78-81. [CrossRef] [PubMed]

146. Wang, H.; Zhong, Z.; Luo, Y.; Cox, E.; Devriendt, B. Heat-Stable Enterotoxins of Enterotoxigenic Escherichia Coli and Their Impact on Host Immunity. Toxins 2019, 11, 24. [CrossRef]

147. Lépine, A.F.P.; de Wit, N.; Oosterink, E.; Wichers, H.; Mes, J.; de Vos, P. Lactobacillus Acidophilus Attenuates Salmonella-Induced Stress of Epithelial Cells by Modulating Tight-Junction Genes and Cytokine Responses. Front. Microbiol. 2018, 9. [CrossRef] 
148. Martins, F.S.; Dalmasso, G.; Arantes, R.M.E.; Doye, A.; Lemichez, E.; Lagadec, P.; Imbert, V.; Peyron, J.-F.; Rampal, P.; Nicoli, J.R.; et al. Interaction of Saccharomyces Boulardii with Salmonella Enterica Serovar Typhimurium Protects Mice and Modifies T84 Cell Response to the Infection. PLoS ONE 2010, 5, e8925. [CrossRef]

149. Helmy, Y.A.; Kassem, I.I.; Kumar, A.; Rajashekara, G. In Vitro Evaluation of the Impact of the Probiotic E. Coli Nissle 1917 on Campylobacter Jejuni's Invasion and Intracellular Survival in Human Colonic Cells. Front. Microbiol. 2017, 8. [CrossRef]

150. Yi, H.; Wang, L.; Xiong, Y.; Wang, Z.; Qiu, Y.; Wen, X.; Jiang, Z.; Yang, X.; Ma, X. Lactobacillus Reuteri LR1 Improved Expression of Genes of Tight Junction Proteins via the MLCK Pathway in IPEC-1 Cells during Infection with Enterotoxigenic Escherichia Coli K88. Mediators Inflamm. 2018, 2018, 1-8. [CrossRef]

151. Jariwala, R.; Mandal, H.; Bagchi, T. Indigenous Lactobacilli Strains of Food and Human Sources Reverse Enteropathogenic E. Coli O26:H11-Induced Damage in Intestinal Epithelial Cell Lines: Effect on Redistribution of Tight Junction Proteins. Microbiology 2017, 163, 1263-1272. [CrossRef] [PubMed]

152. Paparo, L.; Tripodi, L.; Bruno, C.; Pisapia, L.; Damiano, C.; Pastore, L.; Berni Canani, R. Protective Action of Bacillus Clausii Probiotic Strains in an in Vitro Model of Rotavirus Infection. Sci. Rep. 2020, 10, 12636. [CrossRef] [PubMed]

153. Gopalakrishnan, S.; Pandey, N.; Tamiz, A.; Vere, J.; Carrasco, R.; Somerville, R.; Tripathi, A.; Ginski, M.; Paterson, B.; Alkan, S. Mechanism of Action of ZOT-Derived Peptide AT-1002, a Tight Junction Regulator and Absorption Enhancer. Int. J. Pharm. 2009, 365, 121-130. [CrossRef]

154. Coyne, C.; Bergelson, J. CAR: A Virus Receptor within the Tight Junction. Adv. Drug Deliv. Rev. 2005, 57, 869-882. [CrossRef] [PubMed]

155. Stadnyk, A.W. Intestinal Epithelial Cells as a Source of Inflammatory Cytokines and Chemokines. Can. J. Gastroenterol. 2002, 16, 241-246. [CrossRef] [PubMed]

156. Capaldo, C.T.; Nusrat, A. Cytokine Regulation of Tight Junctions. Biochim. Biophys. Acta BBA Biomembr. 2009, $1788,864-871$. [CrossRef] [PubMed]

157. Lechuga, S.; Ivanov, A.I. Disruption of the Epithelial Barrier during Intestinal Inflammation: Quest for New Molecules and Mechanisms. Biochim. Biophys. Acta BBA Mol. Cell Res. 2017, 1864, 1183-1194. [CrossRef]

158. Man, S.M. Inflammasomes in the Gastrointestinal Tract: Infection, Cancer and Gut Microbiota Homeostasis. Nat. Rev. Gastroenterol. Hepatol. 2018, 15, 721-737. [CrossRef]

159. Ogle, C.K.; Hasselgren, P.O.; Ogle, J.D.; Alexander, J.W. The Gut as a Source of Inflammatory Cytokines after Stimulation with Endotoxin. Eur. J. Surg. 1997, 163, 45-51.

160. Tazuke, Y.; Drongowski, R.A.; Teitelbaum, D.H.; Coran, A.G. Interleukin-6 Changes Tight Junction Permeability and Intracellular Phospholipid Content in a Human Enterocyte Cell Culture Model. Pediatr. Surg. Int. 2003, 19, 321-325. [CrossRef] [PubMed]

161. Wu, J.; He, C.; Bu, J.; Luo, Y.; Yang, S.; Ye, C.; Yu, S.; He, B.; Yin, Y.; Yang, X. Betaine Attenuates LPS-Induced Downregulation of Occludin and Claudin-1 and Restores Intestinal Barrier Function. BMC Vet. Res. 2020, 16, 75. [CrossRef]

162. Rao, R. Oxidative Stress-Induced Disruption of Epithelial and Endothelial Tight Junctions. Front. Biosci. 2008, 13, 7210. [CrossRef]

163. Buffie, C.G.; Pamer, E.G. Microbiota-Mediated Colonization Resistance against Intestinal Pathogens. Nat. Rev. Immunol. 2013, 13, 790-801. [CrossRef] [PubMed]

164. Libertucci, J.; Young, V.B. The Role of the Microbiota in Infectious Diseases. Nat. Microbiol. 2019, 4, 35-45. [CrossRef] [PubMed]

165. Ducarmon, Q.R.; Zwittink, R.D.; Hornung, B.V.H.; van Schaik, W.; Young, V.B.; Kuijper, E.J. Gut Microbiota and Colonization Resistance against Bacterial Enteric Infection. Microbiol. Mol. Biol. Rev. 2019, 83. [CrossRef] [PubMed] 